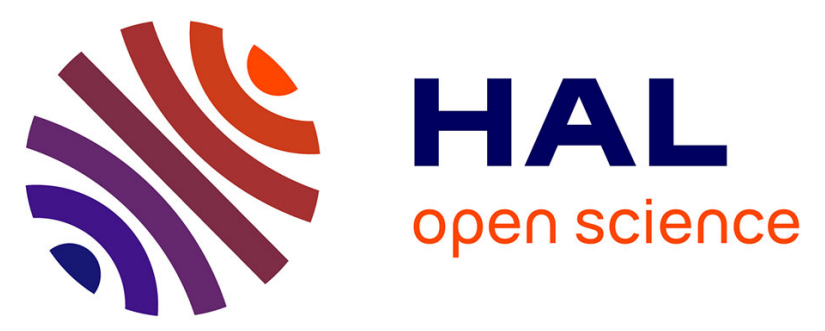

\title{
Mesozoic magmatism and granitic dome in the Wugongshan Massif, Jiangxi province and their genetical relationship to the tectonic events in southeast China
}

\author{
D.Z. Wang, Liangshu S. Shu, Michel Faure, Sheng Zhan
}

\section{- To cite this version:}

D.Z. Wang, Liangshu S. Shu, Michel Faure, Sheng Zhan. Mesozoic magmatism and granitic dome in the Wugongshan Massif, Jiangxi province and their genetical relationship to the tectonic events in southeast China. Tectonophysics, 2001, 339, pp.259-277. 10.1016/S0040-1951(01)00130-5 . hal00089829

\section{HAL Id: hal-00089829 \\ https://hal-insu.archives-ouvertes.fr/hal-00089829}

Submitted on 10 Jul 2007

HAL is a multi-disciplinary open access archive for the deposit and dissemination of scientific research documents, whether they are published or not. The documents may come from teaching and research institutions in France or abroad, or from public or private research centers.
L'archive ouverte pluridisciplinaire HAL, est destinée au dépôt et à la diffusion de documents scientifiques de niveau recherche, publiés ou non, émanant des établissements d'enseignement et de recherche français ou étrangers, des laboratoires publics ou privés. 


\title{
Mesozoic magmatism and granitic dome in the Wugongshan Massif, Jiangxi province and their genetical relationship to the tectonic events in southeast China
}

\author{
D. Z. Wang' a, L. Sh. Shu ${ }^{a}$, M. Faure ${ }^{b}$ and W. Z. Sheng ${ }^{a}$ \\ ${ }^{a}$ Department of Earth Sciences and State Key Laboratory for Mineral Deposits Research, \\ Nanjing University, 210093 Nanjing, People's Republic of China \\ ${ }^{\mathrm{b}}$ Institut des Sciences de la Terre d'Orléans - ISTO,CNRS - Université d'Orleans, 45067 \\ Orleans 2, France
}

\section{Abstract}

In SE China, a Mesozoic granitic dome coeval to extensional tectonics is exposed in the Wugongshan massif. Its center is occupied by Mesozoic granitoids and granitic gneisses, and the E-W-trending Late-Paleozoic-Mesozoic Pingxiang and Anfu basins are located along its northern and southern sides, respectively. In this paper, the petrological, geochemical (major, incompatible, and rare earth elements) and isotopic characteristics of the granitoids and granitic gneisses of this dome allow us to constrain their geodynamic evolution.

The Wugongshan Mesozoic K-feldspar-enriched granitoids consist of six granitic bodies and lie within a Paleozoic metamorphic basement. The Caledonian Shanzhuang granodiorite, containing some dioritic enclaves, occurs in the study area and is a calc-alkaline type granodiorite characterised by lower $\mathrm{SiO}_{2}$ and composed of andesine, biotite, quartz, hornblende, magnetite and sphene. The Mesozoic granitoids, either Indosinian plutons or Yanshanian bodies, show a geochemical affinity of peraluminous S-type granite, having higher $\mathrm{SiO}_{2}, \mathrm{~K}_{2} \mathrm{O}$ contents, $\mathrm{Al}>\mathrm{K}+\mathrm{Na}+2 \mathrm{Ca}$, enriched in $\mathrm{Rb}$, Th and depleted in $\mathrm{Eu}$. They also exhibit LREE-enriched patterns and marked negative Eu anomalies. The Yanshanian plutons also contain characteristic minerals such as sillimanite, garnet and monazite.

The Wugongshan Mesozoic granitoids have higher $I_{\mathrm{Sr}}$ values $(0.70981-0.72885)$ and lower $\varepsilon$ ${ }_{\mathrm{Nd}}(T)(-10.6$ to -14.7 ; an average of -12.6$)$ than those of the early Paleozoic Shanzhuang granodiorite. The Mesozoic granitoids were likely derived from ancient sedimentary rocks by partial melting.

The Wugongshan Mesozoic granitoids contain three petrological zones, that is, an Early Cretaceous massive granitic zone in the core (Zone I), a foliated granitic zone (Zone II) and a Triassic granitic gneissic zone in the outer-rim (Zone III). The petrological and geochemical features of massive granitoids (Zone I) are similar to those of foliated granites (Zone II) and of granitic gneisses (Zone III) in this Mesozoic dome. Moreover, geometric and kinematic features within the ductile parts (Units 2 and 3) are also similar to those within the brittle part (Unit 1) of the dome. All these features show that the geologic evolution of the Wugongshan doming is a continuous process lasting from Triassic to Early Cretaceous time. Published ${ }^{40} \mathrm{Ar} /{ }^{39} \mathrm{Ar}$ and $\mathrm{K}-\mathrm{Ar}$ ages in the Wugongshan Mesozoic granitic rocks fall into two major age fields, corresponding to two geodynamic events of intracontinental deformation and magmatic activity. The first tectonothermal event, dated at 226-259 Ma on the granitic gneisses in the outer-rim of dome, can be linked to Indosinian collision between the South China plate and the North China plate during Triassic time. The second event took place during the Early 
Yanshanian, dated at 180-120 Ma on the granites of the core of dome, and are responsible for final doming of the Wugongshan plutons. This event may be related to a westward subduction of the Paleo-Pacific oceanic plate under the SE-China continent during Late Jurassic-Early Cretaceous time.

Author Keywords: Wugongshan granitic dome; petrology; geochemistry; Mesozoic tectonic

\section{Introduction}

Mesozoic volcanic and granitic rocks occupy a huge area of Southeast China. They are a key to understanding Mesozoic tectonic framework and geological evolution of Eastern Asia. The Southeast China Continent is divided by the Pingxiang-Jiangshan-Shaoxing fault and the Zhenghe-Dapu fault (see inset of Fig. 1, marked as (1) and (2), respectively) into three blocks. They are, from NW to SE successively, the Yangzi Block, the South China Caledonian Fold Belt (with a Precambrian metamorphosed basement), and the Southeastern China Coastal Mesozoic Volcanic Belt (including the Taiwan Central Ranges). The study area is located in the middle segment at the northeastern margin of the South China Caledonian Fold Belt, adjacent to the Pingxiang-Jiangshan-Shaoxing fault. The latter is considered to be a very important tectonic suture (Guo; Guo; Shu; Charvet and Ren).

The Coastal Volcanic Belt has long been recognized as a NE-trending calc-alkaline igneous arc resulting from a westward or northwestward subduction of the Paleo-Pacific oceanic plate under the Southeast China Continent during the Late Jurassic-Early Cretaceous (Jahn and Jahn), succeeded by a collision during late Early Cretaceous (Early Yanshanian) and an intracontinental rifting beginning in early Late Cretaceous time (Late Yanshanian) ( $\mathrm{Xu}$ and Faure). Differing from the Coastal Volcanic Belt, the Late Yanshanian bimodal magmatism is weakly developed within the South China Fold Belt. According to JBGMR; FBGMR and ZBGMR, the South China Caledonian Fold Belt recorded three tectonic events. A preDevonian event, called 'Caledonian orogeny', building the outline of the South China Caledonian Fold Belt, is demonstrated by a regional Late Devonian unconformity, folding of Precambrian to Early Paleozoic sequences, and intrusion of Silurian granitoid; the second event, 'Indosinian tectonism', that took place during Triassic time ( $\mathrm{Lu}$ and $\mathrm{Xu}$ ), is demonstrated by a regional Late Triassic unconformity and the intrusion of several PermianTriassic plutons; the third tectonothermal event, 'Early Yanshanian magmatic event', related to the westward subduction of the Paleo-Pacific plate, took place mainly during JurassicCretaceous time, leading to large scale intracontinental faulting and development of granitic plutons that intruded the pre-Mesozoic rocks which are overlain by the Late Cretaceous red beds. The third event also led to magma-doming and crustal extension followed by the formation of fault-bounded NE-SW-trending small basins containing Late Jurassic-Early Cretaceous volcanic-sedimentary sequences.

Recently, an extensional Wugongshan granitic dome was recognized within the South China Caledonian Fold Belt in the western part of Jiangxi Province (Faure and Shu). Based on its geometric and kinematic features and precise dating of ductile shear deformation, Faure et al. (1996) proposed that the formation of Wugongshan metamorphic core complex was the result of a Triassic tectonothermal event overprinted by a Cretaceous synkinematic plutonism. 
Up to now, all works on the Wugongshan granitic dome are on the level of geometry and kinematics. Petrology and geochemistry of this dome have been poorly understood. In this paper, we document mainly petrological and geochemical features including REE patterns and $\mathrm{Nd}$ and $\mathrm{Sr}$ compositions of this Mesozoic dome, as well as related isotopic ages to constrain the geodynamic evolution of this extensional regime.

\section{Geological feature}

\subsection{Structural outline}

The Wugongshan dome, located in the middle segment of the South China Caledonian Fold Belt and adjacent to the Neo-Proterozoic Jiangnan Belt of the Yangzi Block, exhibits an elliptical morphology: an E-W-trending long axis of $100 \mathrm{~km}$ from Pingxiang to Xinyu and a $\mathrm{N}-\mathrm{S}$-trending short axis of $50-60 \mathrm{~km}$ from Yichun to Anfu (Fig. 1). Its axial zone, the Hongjiang-Wanlongshan zone that crops out along the ridges of mountains, consists of granitic gneisses and foliated Mesozoic granitic plutons. Toward slopes on both sides of the ridge, mylonitized gneissic granites with small ptygmatic veins, granitic gneiss, micaschist and phyllite are asymmetrically distributed. The Pingxiang and the Anfu Late PalaeozoicMesozoic sedimentary basins occur in northern and southern depressions, respectively. Rocks in both basins were folded into recumbent, asymmetric folds at various scale. Neither Mesozoic volcanic lava nor volcaniclastic rocks were found around this dome.

The inner part of the dome consists of a Neo-Proterozoic and Sinian (the uppermost part of Proterozoic) metamorphic series. Weakly metamorphosed Cambrian-Ordovician sedimentary rocks occur in the outer rim of the dome. In turn, the folded Late Palaeozoic-Mesozoic sedimentary rocks are exposed in the surrounding piedmont.

\subsection{Stratigraphic sequence}

From upper to lower, the rock sequences are: Upper Cretaceous: red conglomerate and coarse-grained sandstone, unconformably overlying Triassic clastic rocks and folded Upper Palaeozoic sedimentary rocks.

Jurassic-Upper Triassic: red mudstone, sandstone and conglomeratic rocks.

Lower Triassic-Permian-Carboniferous: gray sandstone, shale, limestone, marl and dolomite that were ductily sheared near the granitic dome.

Upper Devonian: white color quartz-sandstone and quartzite, unconformably overlying the Sinian schist-gneiss in the northern slope of the ridge and the Cambrian or Ordovician phyllite series in the southern slope of the ridge. Along the northern margin of Anfu basin, these sandstones and quartzites were strongly mylonitized.

Ordovician and Cambrian: meta-volcanic turbidite, graywacke and phyllite.

Sinian: schistose tuff, graywacke, siliceous rock series interlayered with iron beds in the outer rim of the dome, and micaschist and gneiss interlayered with siliceous rocks in the inner part of the dome. 
Upper Proterozoic (Shenshan Group): micaschist and phyllite within the dome and schistose volcaniclastic rocks interlayered with meta-basalts, spilites and ultramafic rocks outside of the dome.

Moreover, Silurian, Middle Triassic and Early Cretaceous rocks are lacking in the study area.

\subsection{Geometric and kinematic features}

Structurally, this dome-type extensional tectonic regime can be divided into three units: Unit 1 is a brittlely deformed unit, composed of S-N-trending normal faults and folded-fractured Late Paleozoic-Mesozoic limestones and sandstones in the Pingxiang and Anfu basins (Fig. 2); Unit 2 is a ductilly deformed unit comprising low-grade greenschist facies Early Paleozoic to Sinian slates and phyllites; Unit 3 consists of the Mesozoic granites, granitic gneisses and micaschists.

Units 2 and 3 form the Wugongshan metamorphic core complex, which was developed on the basement of Caledonian sequences containing the Shanzhuang granodiorite to the southeast. Two large ductile normal faults are present between Unit 1 and Unit 2; they are named the Xinyu-Yichun fault and the Shanzhuang-Yantian fault on the northern and southern slopes of the mountain, respectively (Fig. 1).

The N-S-trending ductile lineations on both sides define a dip-slip motion. Various macroand microscopic kinematic criteria ( $\mathrm{S}-\mathrm{C}$ composite foliation, asymmetric porphyroclastic system of feldspar or quartz, mineral pressure shadows, rotated garnet and feldspar etc.) indicate the sense of shear: top-to-the- $\mathrm{N}$ for the northern slope and top-to-the-S for the southern slope. Geometric and kinematic features within the ductile parts are similar to those within the brittle parts of the dome.

The upper limit of the age of deformation in this dome is roughly constrained as pre-Late Cretaceous time by two geologic observations: (1) sub-horizontal Late Cretaceous red beds lie unconformably on the folded and faulted Triassic and Jurassic rock series and (2) occurrence of gneiss or granitic gneiss pebbles in Tertiary conglomerates (JBGMR, 1984).

\subsection{Metamorphic minerals in the granite dome}

Typical metamorphic minerals occurring in Unit 3 of the Wugongshan dome include sillimanite, garnet, muscovite, biotite, chlorite and sericite. Most of sillimanite and garnet grains are found within or around the Qinglongshan Yanshanian granite core, developing mainly in the gneissose granite. Sigmoid muscovite and biotite are very common in the gneissose granites, gneisses and micaschists. Chlorite and sericite are often overprinted on feldspar and mica in Unit 3, although they are common metamorphic minerals of slate and phyllite of Unit 2. It is worth noting that foliated granitoids, granitic gneisses and micaschists in Unit 3 and slate-phyllite rocks in Unit 2 present a geometric accordance of foliations and lineations, implying that these metamorphic minerals and kinematic fabrics, at least some parts, were likely caused by granitic doming.

Granitic rocks in the granite core contain also some micrograins of sillimanite and garnet (WG27, 45, 47, Fig. 3 and Table 2). Unlike larger metamorphic grains in sample WG51 of the outer rim, tiny sillimanite and garnet of the inner rim seem to be magmatic minerals without any metamorphic or ductilly deformed textures. 
No sillimanite or garnet grains were found in the Indosinian Zhangjiafang granite due to limited outcrops and severe weathering of the rocks.

\subsection{Syn-tectonic and pre-tectonic plutons}

We use the available geochronological data to delineate thermal events and to constrain tectonic interpretation of the Wugongshan dome (Fig. 1). From the published age data ( JBGMR; Yin; Faure and Shu), two phases of tectonothermal events took place in the central part of the dome, which consists of six plutons: an Indosinian and five Yanshanian granitic plutons. The latter, occupying a total area of $300 \mathrm{~km}^{2}$, is dated at $132-136 \mathrm{Ma}$ by ${ }^{40} \mathrm{Ar} /{ }^{39} \mathrm{Ar}$ and $\mathrm{K}-\mathrm{Ar}$ geochronological methods, and the former, occurring in the western part of the dome and covering about $30 \mathrm{~km}^{2}$, is dated at $226-259 \mathrm{Ma}$ by ${ }^{40} \mathrm{Ar} /{ }^{39} \mathrm{Ar}$ and $\mathrm{K}-\mathrm{Ar}$ methods (Fig. 1).

These six plutons are found in the cores of antiforms and form syn-tectonic bodies. They show various ductile structures along their margins, and weakly or non-mylonitic fabric in the magmatic core, indicating a continuous evolution of a syn-tectonic pluton from plastic deformation along its rim to 'magmatic' fabric in its core.

A pre-tectonic pluton is represented by the Shanzhuang granodiorite, covering $70 \mathrm{~km}^{2}$. It is located in the SE margin of the dome and dated at 411 Ma by the whole-rock Rb-Sr isochron method (Tang et al., 1991) and at 403 Ma by the K-Ar method on muscovite (JBGMR, 1984; Fig. 1). Unlike the Mesozoic plutons, this pre-tectonic pluton is characterized by intense gneissification, NW-trending stretching lineation and NE-striking foliation structures that penetrate the whole body. As shown by post-solidus textures, the deformation of the Shanzhuang granodiorite is unrelated to magmatic doming.

North of Hongjiang on the northern flank of the dome is a mylonitized augen granitic gneiss with a stretching lineation plunging $\mathrm{N} 310^{\circ}$ on a $\mathrm{N} 65^{\circ} \mathrm{E}$ striking foliation plane, in which a top-to-the-SE sense of shear is shown by $\mathrm{S}-\mathrm{C}$ composite foliation and asymmetric feldspar porphyroclasts. Such an abnormal sense of shear has never been found elsewhere in the dome, and is interpreted as a pre-doming structure related to the Caledonian event (Faure et al., 1996).

\section{Petrology of granitoids in the dome}

Seven plutons are exposed in the dome area. They are, from $\mathrm{W}$ to $\mathrm{E}$, the Zhangjiafang, the Xinquan, the Qinglongshan, the Wentang, the Yashan, the Shongshan and the Shanzhuang bodies (Fig. 1). The Qinglongshan granitic body with an outer rim of granitic gneiss and a core of granite is the largest, $>100 \mathrm{~km}^{2}$, and the Shanzhuang granodiorite is the oldest. These granitoids were emplaced during three magmatic events: the Caledonian (JBGMR and Tang), the Late Indosinian and the Early Yanshanian ( Faure and Shu). The Shanzhuang Caledonian body was intruded by two small Yanshanian leucogranites ( Fig. 1). The Zhangjiafang foliated granite is Indosinian, and other five bodies are Early Yanshanian. The Yashan pluton is a granite with intense albitization, yields a large $\mathrm{Ta}-\mathrm{Nb}-\mathrm{Li}$ deposit and its petrological and geochemical characteristics have been discussed by Yin et al. (1995). 


\subsection{Shanzhuang pre-tectonic granodiorite}

The Shanzhuang granodiorite with porphyritic or augen structure consists of phenocrysts of andesine $(\mathrm{An}=30-40,10-15 \%)$ (Table 3$)$, biotite $(10 \%)$, quartz $(10 \%)$, hornblende $(2-5 \%)$, and groundmass grains $(65 \%)$ of oligoclase (An15-20)+quartz+microcline + muscovite+biotite, as well as accessory minerals (1\%) of zircon+rutile+sphene+magnetite. Some oligoclase grains (An15-20) were found also along the margins of andesine phenocrysts. This pluton intruded Sinian and Cambrian metamorphic rocks and is unconformably overlain by Upper Devonian sandstone in its southern margin near Anfu. Dioritic rocks were involved in the Caledonian magmatism, and several dioritic enclaves, of $50-180 \mathrm{~cm}$ in diameter are present in the SE margin of the pluton. These dioritic enclaves, mainly composed of plagioclase and hornblende (Table 1), are geochemically similar to the granodiorite (Fig. 5A and B), suggesting that the dioritic enclaves and the Shanzhuang granodiorite are co-genetic.

This granodiorite has undergone two phases of metamorphism. The first metamorphism of amphibolite facies is characterized by curved amphibole grains, asymmetric plagioclase augens, sigmoidal biotite and muscovite in granitic gneisses (Table 1 and Table 2). The second metamorphism of lower greenschist facies is characterized by scaly sericite, chlorite, albite and quartz aggregates or fine veins, which are mainly developed along fissures of gneissose granodiorite. Microscopically, biotite and brown hornblende are usually altered to chlorite rimmed by Fe-rich oxides, and andesine grains are replaced by chlorite, sericite and kaolinite, suggesting that the second phase is a retrogressive metamorphism. We assume that the second phase metamorphism was related to the Mesozoic Wugongshan extensional tectonism.

\subsection{Wugongshan syn-tectonic granitoids}

Most granitoids in the study area are syntectonic with a core of weakly foliated granite and a rim of granitic gneiss containing sub-N-S mineral and stretching lineations. The syn-tectonic granites are composed of K-feldspar, quartz, muscovite, albite and minor biotite. They are mainly exposed at a higher elevation in the Wugong Mountains. The geochronological data show that the Qinglongshan body is a two-phase complex. Its margin is surrounded by Indosinian granitic gneisses dated at $233.5 \pm 5 \mathrm{Ma}$ (Fig. 1), while its central part is occupied by a $100 \mathrm{~km}^{2}$ Early Yanshanian K-feldspar granite, dated at $131.7 \pm 1.7 \mathrm{Ma}$ (Fig. 1). Some Yanshanian aplite and pegmatite veins intruded the Indosinian granitic gneisses.

\subsection{Lithofacies of syn-tectonic granitic bodies}

The syn-tectonic granites exhibit petrographical facies zoning. The most marked zoning occurs in the Qinglongshan pluton (Fig. 1 and Fig. 3). This pluton is located in Unit 3 and can be divided into three petrographical facies zones with distinct features. Zone I is a massive porphyroidal granite core and is surrounded by Zone II. Zone II is a weakly deformed sillimanite-garnet-bearing granite that is marked by 'crystal mush' structure ( Hibbard, 1987) and well oriented euhedral feldspar phenocrysts. Zone III forms an outer rim of mylonitized gneissose granite, granitic gneiss and micaschist, containing more garnet and mica grains.

The porphyroidal granite of Zone I is represented by samples WG23, WG27, WG35 and WG41 (Table 1). It has a distinctive porphyroidal texture with large phenocrysts and a 
medium-grained groundmass, consistent with a deep crystallization environment. Phenocrysts occupy $20-30 \%$ in volume ( Fig. 4A) and single feldspar phenocrysts are up to $20-30 \times 5-10$ $\mathrm{mm}^{2}$ in size. Most phenocrysts are microcline, and a small part is quartz and albite. The groundmass grains, $2-4 \mathrm{~mm}$ in diameter, occupy $70-80 \%$ in volume and consist of microcline, quartz, muscovite, biotite and minor albite and sillimanite. The accessory minerals include zircon, rutile, monazite, sphene, tourmaline and apatite. Tourmaline is occasionally found in the leucogranite. In zone I, both groundmass and phenocrysts are automorphic. Micrograins of garnet are found in WG27 by electron microprobe. Microcline contains a small amount of albite making up perthite. Synneusis feldspar is widely developed. Myrmekite occurs in the K-feldspar phenocryst or around the boundaries between albite and microcline grains. Coarse biotite and quartz contain inclusions of zircon and rutile in some samples (WG35). The most marked feature of Zone I is that all minerals are not obviously orientated. In thin sections, triple junction and plane boundaries of minerals predominate, suggesting a static recrystallized environment.

Zone II is $500-1000 \mathrm{~m}$ wide and is asymmetrically distributed around Zone I. Both Zones I and II are continuous in lithofacies. Zone II is composed of weakly deformed porphyroidal granite (WG43, WG45, WG47, Table 1) and has similar major mineral compositions to those of Zone I. However, Zone II contains tiny grains of sillimanite and garnet. The garnet is 0.1$0.2 \mathrm{~mm}$ in diameter. Biotite schlierens are often observed in granites of this zone. Compared with Zone I, Zone II displays different structure and mineral size. Both phenocrysts and groundmass grains are hypidiomorphic. K-feldspar phenocrysts are up to $5 \times 20 \mathrm{~mm}$, single grains in the groundmass are $1.5-3 \mathrm{~mm}$. On the outcrop scale, the 'crystal mush' structure occurs widely, indicating 'soft deformation' of granitic magma. The crystal mush structure (Fig. 4B) is characterized by automorphic feldspar and biotite megacrysts and garnet grains. These minerals are surrounded by medium-fine-grained minerals of xenomorphic quartz, microcline and albite. Groundmass and K-feldspar phenocrysts are strongly oriented along a submeridianal direction, forming mineral lineations, which is a high-temperature magmatic fabric. But, the fabric is not mylonitic, even when some large feldspar phenocrysts are almost completely replaced by small quartz and feldspar aggregates.

Zone III is occupied by gneissose granite and granitic augen gneiss (WG51, WG55, WG59), and is $2-5 \mathrm{~km}$ wide. The gneissose rock is composed of hypidiomorphic and xenomorphic augen phenocrysts (15-20\%; Fig. 4C) with 5-10×2-4 $\mathrm{mm}^{2}$ dimensions and a medium-finegrained groundmass $(80 \% \pm)$. Augen porphyroclasts include microcline and quartz. Large sigmoidal flakes of muscovite and biotite are common. The groundmass consists of xenomorphic quartz, microcline, perthite, garnet, biotite, albite and muscovite. Some small grains of garnet and sillimanite appear at the boundaries of K-feldspar augens. They are arranged parallel to the stretching lineation in the gneissose foliation. Biotite and feldspar are occasionally replaced by aggregates of chlorite, sericite and epidote.

The granitic gneisses of Zone III exhibit mylonitic foliation and lineation with a sub-N-Sstrike (Fig. 4D). Various well developed kinematic criteria exhibit ductile shearing. Quartz porphyroclasts and matrix were strongly deformed, producing various ductile microstructures such as elongated and flattened grains, undulatory extinction, shear bands, core-mantle structure, serrated boundaries and dynamically recrystallized subgrains. Feldspar was fractured internally and sheared around its margins, being marked by core-mantle structure, serrated boundaries, asymmetric augen feldspars, and dynamically recrystallized feldspar- 
quartz subgrains. Albite twins in the plagioclase are curved (WG51). Biotite is often replaced by sigmoidal muscovite.

In the gneissose granite between Zone III and Zone II, large K-feldspar phenocrysts are always cracked and form fissures that are filled by micro-aplite veins consisting of xenomorphic quartz and albite grains. Mantle-like myrmekite and crystal mush texture are observed in the gneissose granite. Myrmekite occurs along the long margins of K-feldspar parallel to the foliation, suggesting that myrmekite was exsolved from K-feldspar perpendicular to the maximum shortening. According to previous works (Hibbard; Hibbard; Hutton; Bouchez and Faure), micro-aplite veins, mantle-like myrmekite and crystal mush texture in gneissose granite were formed before the complete crystallization of the magma when the pluton emplaced during tectonic deformation, and the last magmatic fraction was relocated and crystallized in a low-strain setting. These magmatic fabrics, which are considered important evidence of syn-tectonic plutonism, indicate that some granitic gneisses of Zone III were gneissified during emplacement.

Two generations of garnet can be recognized in the granitic gneiss of Zone III: the earlier large and fractured garnet porphyroblasts with tails of dynamically recrystallized subgrains of muscovite, feldspar and quartz (WG53), and the later synmagmatic automorphic garnet micrograins. This is an important evidence for polyphase deformation. Accordingly, granitic gneisses of Zone III were formed prior to Yanshanian granitic doming.

\subsection{EMPA compositions of some minerals of granitic plutons}

Compositions of minerals for six representative samples from the Qinglongshan Mesozoic pluton and one sample (WG13) from the Shanzhuang Caledonian granite were analyzed on a JXA-8800M-type EMPA (electron microprobe analyzer) using a $15 \mathrm{kV}$ accelerating potential and $20 \mathrm{nA}$ beam current at State Key Laboratory for Mineral Deposits Research, Nanjing University. The analyzed minerals include plagioclase, microcline, biotite, muscovite, sillimanite and garnet; also analyzed are porphyroblasts of biotite and muscovite with asymmetric fabrics that are related to extensional shearing. The 40 representative analyses are listed in Table 2.

In the Shanzhuang Caledonian pluton, oligoclase grains display two growth habits: as a groundmass relative to andesine phenocryst and as marginal grains around andesine minerals. The biotite grains of this body have higher $\mathrm{FeO}$ and lower $\mathrm{Al}_{2} \mathrm{O}_{3}$ than those of the Mesozoic granite. But, we did not find any andesine and amphibole in the Mesozoic granites. Albite grains are mainly in the groundmass, and microcline grains are mainly phenocrystic. The

biotite flakes of Zone I and II display lower FeO contents than those of Zone III (WG51, Table 2). Microcline grains of the inner zones have higher $\mathrm{K}_{2} \mathrm{O}$ and lower $\mathrm{Na}_{2} \mathrm{O}$ contents than those (WG51, Table 2) of the outer rim. The garnet micrograins in the granite core have higher almandine (75.2-75.5\%) and lower pyrope component (12.5-13.2\%, WG27, Table 2), however, the garnet grains near the detachment fault of the outer rim are richer in pyrope component (17.8-19.3\%, WG51, Table 2).

\section{Geochemical features and magmatic affinities}

14 representative samples (13 for granite and 1 for dioritic enclave) were analyzed for major, incompatible elements and rare earth elements. Petrographic features of these samples are listed in Table 1, and typical mineral compositions in Table 2. Elemental analyses were 
carried out by ICP at the Center for Materials Analysis, Nanjing University. The analytical results are listed in Table 3.

All samples used for analysis are fresh, not fractured and the least altered, however, slight hydro-metamorphism, which took place after being uplifted up to a higher structural level, cannot be ruled out. For example, chloritization both rimming feldspar or biotite and filling voids in the rock is often observed. Geochemically, it is expressed by loss on ignition (LOI) values of $0.52-2.01 \mathrm{wt} \%$. The highest LOI was in sample WG45 (2.01\% for mica-granite) in the Zone II. The LOIs in the other granites and granitic gneisses do not exceed 1.5\% (Table 3), implying a deeper magmatic environment, consistent with their large phenocrysts and medium-grained groundmass.

\subsection{Shanzhuang pre-tectonic plutons}

The samples of granodiorite (WG13, WG14, WG15; Table 1) and dioritic enclaves (WG13; Table 1 and Table 2) were collected from the Shanzhuang pluton. Compositionally, the first three samples are intermediate-acidic rocks characterized by lower $\mathrm{SiO}_{2}, \mathrm{~K}_{2} \mathrm{O}$, and higher $\mathrm{CaO}, \quad \mathrm{Na}_{2} \mathrm{O}$, TFe and $\mathrm{MgO}$ contents: $\mathrm{SiO}_{2}=66.45-69.56 \% ; \quad \mathrm{CaO}=1.68-3.26 \%$; $\mathrm{K}_{2} \mathrm{O}+\mathrm{Na}_{2} \mathrm{O}=6.8-8.1 \%, \mathrm{Na}_{2} \mathrm{O}>\mathrm{K}_{2} \mathrm{O}, \mathrm{K}_{2} \mathrm{O} / \mathrm{Na}_{2} \mathrm{O}=0.67-0.77 ; \mathrm{MgO}=0.98-1.37 \%$ (Table 2). They have alkalinity index of 2.12-3.02 $\left(\left(\mathrm{Al}_{2} \mathrm{O}_{3}+\mathrm{CaO}+\mathrm{K}_{2} \mathrm{O}+\mathrm{Na}_{2} \mathrm{O}\right) /\left(\mathrm{Al} 2 \mathrm{O} 3+\mathrm{CaO}-\mathrm{K}_{2} \mathrm{O}-\right.\right.$ $\mathrm{Na}_{2} \mathrm{O}$ ) for $\mathrm{wt} \%$ ), and belong to the calc-alkaline rock series. Their ANKC values (Mol $\left.\mathrm{Al} 2 \mathrm{O} 3 /\left(\mathrm{Na}_{2} \mathrm{O}+\mathrm{K}_{2} \mathrm{O}+\mathrm{CaO}\right)\right)$ are $1.05-1.08$. These features of major elements suggest a weak affinity for I-type granitoids in their genesis (Chappell; Taylor and Condie). Their special mineral associasion of hornblende +magnetite+sphene in the granitic rocks also exhibits an affinity of I-type granitoids. WG19 is a dioritic enclave exposed in the plutonic margin; it is intermediate in composition $\left(\mathrm{SiO}_{2} 55.88 \%, \mathrm{MgO} 3.79 \%\right.$; $\mathrm{Cr} 45$ ppm, V 147 ppm; Table 3) and contains abundant $\mathrm{Fe}-\mathrm{Ti}$ oxides $(3 \%)$.

The samples show LREE-enriched patterns (normalized to chrondritic values, Sun and McDonough, 1989) with moderate negative Eu anomalies $\left(\mathrm{Eu} / \mathrm{Eu}^{*}=0.58-0.7\right)$ (Fig. 5A, Table 3). Their ORG-normalized spidergram ( Fig. 5B; Pearce et al., 1984) displays a depletion in $\mathrm{Ba}, \mathrm{Nb}$ and an enrichment in $\mathrm{Rb}, \mathrm{Ce}, \mathrm{Th}, \mathrm{Nb} / \mathrm{Y}=0.33-0.51$. WG 19 (dioritic enclave) has the similar incompatible and rare earth element signatures as the other three samples ( Fig. 5A and B), suggesting that the dioritic enclaves and the granodiorite are likely co-genetic.

\subsection{Wugongshan Mesozoic syn-tectonic granitoids}

Ten samples from the three petrographical zones of the Qinglongshan granite were used for petrographic and geochemical study. The analytical results suggest that the three zones are not obviously different in their major element composition (Table 3), however they display different textures, metamorphic and deformational structures ( Table 1 and Fig. 2 and Fig. 3), and trace element signatures.

Compared with the Shanzhuang Caledonian pluton, mineral compositions of the Qinglongshan granitic rocks are poorer in plagioclase and biotite, and richer in microcline. In chemical composition, all samples are peraluminous, K-rich and silica-saturated, marked by low TFe $\left(\mathrm{Fe}_{2} \mathrm{O}_{3}+\mathrm{FeO}\right)\left(1.1-2.8 \%\right.$ for Zone I; $<1.5 \%$ for Zone II and III), high $\mathrm{SiO}_{2}(71.69-$ $74.66 \mathrm{wt} \%$ ), high $\mathrm{K}_{2} \mathrm{O}+\mathrm{Na}_{2} \mathrm{O}$ (7-9\%), $\mathrm{K}_{2} \mathrm{O}>\mathrm{Na}_{2} \mathrm{O}$ and $\mathrm{K}_{2} \mathrm{O} / \mathrm{Na}_{2} \mathrm{O}=1.1-2.0$ (Table 3). 
However, sample WG59 ( Fig. 3) shows an abnormal $\mathrm{K}_{2} \mathrm{O} / \mathrm{Na}_{2} \mathrm{O}$ RATIO=0.74 due to the albitization of rock, which was likely developed during the late magmatic stage (Yin et al., 1995). The $\mathrm{CaO}, \mathrm{TFe}$ and $\mathrm{MgO}$ contents are lower. Their alkalinity index is 2.9-3.8, the ANKC values are 1.11-1.32 ( Table 3), suggesting a K-rich calc-alkaline affinity. Their specific mineral association is muscovite+garnet, with occasional sillimanite. All these features show a geochemical affinity of peraluminous S-type granite.

From Table 3 and Fig. 5C-H, all samples are LREE-enriched: (La/Yb)n 4.1-11.5, mean 7.29 for 10 samples and exhibit negative Eu anomalies: $\mathrm{Eu} / \mathrm{Eu}^{*}=0.83-0.21$, average 0.5, indicating a marked fractionation between LREE and HREE. Their incompatible element patterns, normalized to ORG (Fig. 5D,F and $\mathrm{H}$ ) show a depletion in $\mathrm{Ba}$ and an enrichment in $\mathrm{Rb}$ and Th, showing a typical feature of peraluminous intrusions ( Harris et al., 1986). Thus, the contribution of ancient Precambrian crustal components is implicated for the petrogenesis of the Wugongshan granitoids.

Some compositional differences were found in three zones of the Qinglongshan Mesozoic granite. For Zone I, the 4 samples (WG23, 27, 35, 41, Fig. 3) of non-oriented porphyroidal granite have the highest REE contents $(222.62-249.69 \mathrm{ppm})$. They show LREE-enriched patterns $((\mathrm{La} / \mathrm{Yb}) n$ 4.1-9.1, mean 6.6) (Fig. 5C; Table 3), with negative $\mathrm{Eu}$ anomalies $\left(\mathrm{Eu} / \mathrm{Eu}^{*}=0.54-0.83\right.$, average 0.66$)$. Their ORG-normalized diagrams show a gradual enrichment in $\mathrm{Ce}$ and $\mathrm{Sr}$, and a gradual depletion in $\mathrm{Zr}$ from Zone I, through Zone II to Zone III. This continuous evolution in composition agrees well with the field and petrographic observations.

Differing from Zone I and Zone II, samples WG 51, 55, 59 (Table 3, Fig. 3) in Zone III (Indosinian gneissose granite) have the higher REE contents: $159.74-185.88 \mathrm{ppm}$. They are LREE-enriched with $(\mathrm{La} / \mathrm{Yb}) n$ of 7-10.4 (a mean of 8.2) and show moderate to marked negative $\mathrm{Eu}$ anomalies of $\mathrm{Eu} / \mathrm{Eu}^{*}=0.37-0.52$ (Fig. 5G). Their incompatible element patterns, normalized to ORG ( Fig. $5 \mathrm{H}$ ) exhibit a marked depletion in $\mathrm{Nb}$, and higher contents of $\mathrm{Rb}$, $\mathrm{Th}, \mathrm{Ce}$ and $\mathrm{Sr}$, indicative of S-type granite.

\section{Isotope geochemistry}

\subsection{Samples and analytical methods}

Seven representative whole-rock samples (WG13, 19, 23, 41, 143, 59 and 91 in Table 4. Sampling locations are shown in Fig. 1, Fig. 2 and Fig. 3) for $\mathrm{Nd}-\mathrm{Sr}$ isotopic compositions were analyzed by Prof. Huang in the Isotopic Laboratory, Institute of Geology (Beijing), Academia Sinica. The detailed procedures for analysis of isotopic compositions have been previously described ( DePaolo, 1988). Samples WG13 and 19 are from the Shanzhuang granodiorite, WG91 from the Zhangjiafang Indosinian granite, WG143 is a sample of the Yashan granite, and the other three samples are from the Qinglongshan Mesozoic pluton. Besides, the published isotopic data for six samples in the study area ( Liu and $\mathrm{Xu}$ ) are also cited in the table.

The isotopic compositions were carried out on a VG-354 mass spectrometer. Concentrations of $\mathrm{Sm}, \mathrm{Nd}, \mathrm{Rb}$ and $\mathrm{Sr}$ were determined by the isotopic dilution method. Uncertainties herein represent $2 \mathrm{\sigma m}$ errors. Normalization values are ${ }^{86} \mathrm{Sr} /{ }^{88} \mathrm{Sr}=0.1194$ for $\mathrm{Sr}$ and ${ }^{146} \mathrm{Nd} /{ }^{144} \mathrm{Nd}=0.7219$ for $\mathrm{Nd}$. The decay constants used are $\lambda\left({ }^{147} \mathrm{Sm}\right)=0.00654 \mathrm{Ga}^{-1}$, and $\lambda\left({ }^{87} \mathrm{Rb}\right)=0.0142 \mathrm{Ga}^{-1}$. The blank levels are $10^{-10}-10^{-11} \mathrm{~g}$ for $\mathrm{Rb}$ and $\mathrm{Sr}$, and $10^{-11}-10^{-12} \mathrm{~g}$ for 
Sm and $\mathrm{Nd}$, respectively. The ${ }^{86} \mathrm{Sr} /{ }^{88} \mathrm{Sr}$ ratios are reported relative to NBS SRM-987 $\mathrm{Sr}$ STANDARD $=0.710260 \pm 12(2 \mathrm{\sigma m})$ and the ${ }^{143} \mathrm{Nd} /{ }^{144} \mathrm{Nd}$ ratios are reported relative to La Jolla $\mathrm{Nd}$ STANDARD $=0.51185 \pm 3(2 \mathrm{\sigma m})$. Initial $\mathrm{Sr}$ and $\mathrm{Nd}$ compositions of samples are shown as $I_{\mathrm{Sr}}$ and $\boldsymbol{\varepsilon}_{\mathrm{Nd}}$. Results are listed in Table 4.

Since $\mathrm{Sm} / \mathrm{Nd}$ ratios of the analyzed samples vary from 0.157 to 0.279 , we adopt the formula of two stage model ages to calculate $\mathrm{Nd}$ model ages $\left(T_{\mathrm{DM}}\right)$ related to $\mathrm{Sm}-\mathrm{Nd}$ fractionation during crustal evolution, aiming at reducing the $T_{\mathrm{DM}}$ calculation error caused by the formula of single stage model age.

\subsection{Nd-Sr isotope geochemistry}

Granitoids of the Wugongshan complex have higher $I_{\mathrm{Sr}}$ values $(>0.710)$, lower $\varepsilon_{\mathrm{Nd}}$ values $(-10.0$ to -14.9$)$ and older $T_{\mathrm{DM}}$ values $(>1.8 \mathrm{Ga})$ (Table 4$)$. These features together with the distinct negative $\mathrm{Ba}$ anomalies and positive $\mathrm{Rb}$ and $\mathrm{Th}$ anomalies (shown in Fig. 5D, F and $\mathrm{H}$ ) appear to indicate a higher crustal maturity, a typical feature of S-type granites.

Various granitic bodies formed in different magmatic stages display different isotopic compositions. The Caledonian Shanzhuang granodiorite has $I_{\mathrm{Sr}}=0.70661, \varepsilon_{\mathrm{Nd}}=-12.0$, $T_{\mathrm{DM}}=2128 \mathrm{Ma}$; the Indosinian Zhangjiafang granite has $I_{\mathrm{Sr}}=0.70981, \varepsilon_{\mathrm{Nd}}=-10.5, T_{\mathrm{DM}}=1870$ $\mathrm{Ma}$; the Indosinian Wugongshan gneissose granites have $I_{\mathrm{Sr}}=0.71557-0.72885, \varepsilon_{\mathrm{Nd}}=-12.7$ to $-10.9, \quad T_{\mathrm{DM}}=1896-2061 \mathrm{Ma}$; the early Yanshanian Yashan pluton has $\varepsilon_{\mathrm{Nd}}=-12.0$, $T_{\mathrm{DM}}=2050 \mathrm{Ma}$ and the early Yanshanian Qinglongshan granites have $I_{\mathrm{Sr}}=0.716958, \varepsilon$ $\mathrm{Nd}=-14.9$ to $-11.1, T_{\mathrm{DM}}=1825-2055 \mathrm{Ma}$. These isotopic geochemical features suggest that the $\varepsilon_{\mathrm{Nd}}$ and $I_{\mathrm{Sr}}$ values in the Wugongshan complex are varied not only among granitoids formed in different magmatic stages, but also for different spatial positions within a pluton.

We conclude that the Wugongshan granitic complex has higher $I_{\mathrm{Sr}}$ values, lower $\mathbb{E}_{\mathrm{Nd}}$ values, older $T_{\mathrm{DM}}$ ages and typical features of S-type granitoids, suggesting that their magma source was composed of ancient crustal materials with few or no mantle-derived components. In the $\varepsilon_{\mathrm{Nd}}$ Vs. time diagram (Fig. 6), regardless of rock types and formation stages, all samples from the Wugongshan complex fall into the evolution field of Sm-Nd components of the Middle Proterozoic meta-sedimentary rocks in the southern Jiangxi (MPRSJ) including the areas studied by Xie and $\mathrm{Hu}$. These meta-sedimentary rocks from the older basement are certainly not a direct material source for the Wugongshan granitoids. Nevertheless, the similarity of Nd isotopic compositions between the Wugongshan granitoids and the Middle Proterozoic metasedimentary rocks in southern Jiangxi implies a crustal source for granitoids in the study area. Thus, the contribution of ancient Precambriam crustal components is documented in the petrogenesis of the Wugongshan granitic complex and they were likely formed by partial melting of ancient crustal rocks.

\section{Relationship with the Mesozoic tectonic events in Southeast China}

Within the South China Fold Belt, the Wugongshan extensional tectonism was developed on a Caledonian metamorphic basement. The Wugongshan Mesozoic granitoids are S-type, derived from partial melting of crustal materials including Proterozoic and Early Paleozoic rocks. Their development can be linked to two important geodynamic events, the Indosinian and the Early Yanshanian events. 
The first event took place during Late Triassic time (220-240 Ma) and produced ductile shear deformation on large detachment faults along pre-existing Late Devonian discontinuities. It can be linked to collisions between the South China and North China blocks (Xu; Wang; Guo; Faure and Ren). In the South China Caledonian Fold Belt, this event is very strong and widespread, causing not only uplifting of Dabie suture belt, but also the intra-continental ductile folding and thrusting.. In the study area, response to the Indosinian event is demonstrated by a Late Triassic regional unconformity, strong folding and thrusting of preMesozoic strata and ${ }^{40} \mathrm{Ar} /{ }^{39} \mathrm{Ar}$ and $\mathrm{K}-\mathrm{Ar}$ geochronological data of the granitic gneisses, suggesting a marked influence of this event.

The second geodynamic event caused the Early Yanshanian large scale granitic magmatism and the final doming of Wugongshan plutons, and is related to the SE-China Coastal Mesozoic Volcanic Belt. The later developed within the Late Paleozoic basement of metaCarboniferous flysch series. This volcanic belt was initially created by a northwestward subduction of the Paleo-Pacific oceanic plate under the Southeast China Block during the Late Jurassic-Early Cretaceous (Jahn; Jahn and Ren). The 'Early Yanshanian tectonism', characterized by high-K calc-alkaline igneous suites, was followed by collision between the China-Indochina margin and the West Philippine Block during late Early Cretaceous time, i.e. 'the Late Yanshanian event' ( NIGMR and Faure). This event also caused the ChangleNanao strike-slip ductile shear structures ( Charvet et al., 1990) with an ${ }^{40} \mathrm{Ar} /{ }^{39} \mathrm{Ar}$ age of $97 \pm 3 \mathrm{Ma}$ (muscovites, granite). Since Late Cretaceous time, a rifting environment was generated at the continental margins of Southeast China (Taylor and $\mathrm{Ru}$ ), marked by the Late Cretaceous bimodal volcanic rock series and miarolitic granites, indicators of intracontinental rifting, which lasted at least until the Late Tertiary. Though Jahn et al. (1976) has suggested that the subduction zone may have dipped westward or northwestward in the western Pacific region since late Mesozoic time, the location of Mesozoic subduction zone is still controversial. Recently, many geologists ( NIGMR and Wang; Ren et al., 1998) proposed that the zone from the Central Tectonic Line of Japan to the Longitudinal Valley of Taiwan is likely a reasonable candidate.

The Mesozoic subduction event strongly effected the South China fold belt by causing upwelling of asthenospheric mantle magma. As a result of ultra-lithospheric faulting, magmatic heat and fluids were transfered from the mantle to the crust, leading to partial melting of crustal rocks to form S-type granitic magma. The intruding magma can yield a hydrogen ballon effect to enhance wall-rock ductility and to promote rheological changes of the wall-rock softening. In the study area, these granitoids were always emplaced in the cores of antiforms, suggesting an important genetic relationship between granitic emplacement and upright folding. The gravitational instability of wall-rocks, which is induced by magmatic doming, formed large detachment faults and ductile shearing at the deeper crustal levels and brittle deformation at the upper crustal levels, forming the Wugongshan dome-type extensional tectonics. This conclusion is consistent with the above presented petrologic and geochemical evidence. 


\section{Acknowledgements}

Burchfiel B.C. and an anonymous reviewer of Tectonophysics are gratefully acknowledged for their valuable suggestions and many corrections importantly in English which improved the manuscript greatly. Charvet Jacques, Guo Lingzhi, Zhou Xinming, Zhu Jinchu, Yang Minggui and $\mathrm{Lu}$ Xibao are thanked for their helps for this study. The support of the National Science Foundation of China (Key project, No.49632080), through a grant, and facilities provided by the Laboratoire de Geologie Structurale of Orleans University, France are thanked.

\section{References}

Bouchez, J.L., Lister, G.S. and Nicolas, A, 1983. Fabric asymmetry and shear sense in movement zones. Geol. Rundsch. 72, pp. 401-420.

Chappell, B.W. and White, A.J.R., 1974. Two contrasting granite types. Pacif. Geol. 8, pp. 173-174.

Charvet, J, Faure, M., Xu, J.W., Zhu, G., Tong, W.X. and Lin, S.F., 1990. La zone tectonique de Changle-Nanao, Chine du sud-est. C. R. Acad. Sci. Paris 310 II, pp. 1271-1278.

Charvet, J, Shu, L.S., Shi, Y.S., Guo, L.Z. and Faure, M., 1996. The building of South China: collision of Yangzi and Cathaysia blocks, problems and tentative answers. J. Southeast Asian Earth Sci. 13 3-5, pp. 223-235.

Condie, K.C., 1989. Plate Tectonics and Crustal Evolution, Pergamon Press, Oxford 476pp.

DePaolo, D.J., 1988. Neodymium Isotope Geochemistry: An Introduction, Springer, Berlin $187 \mathrm{pp}$.

Faure, M., Marchadier, Y. and Rangin, C., 1989. Pre-Eocene synmetamorphic structure in the Mondoro-Romblon-Palawan area, west Philippines, and implications for the history of Southeast Asia. Tectonics 8 5, pp. 963-979.

Faure, M., Sun, Y., Shu, L.S., Monie, P. and Charvet, J., 1996. Extensional tectonics within a subduction-type orogen. The case study of the Wugongshan dome (Jiangxi Province, southeastern China). Tectonophysics 263, pp. 77-106.

Faure, M., Lin, W. and Sun, Y., 1998. Doming in the southern foreland of the Dabieshan (Yangtze block, China). Terre Nova 10, pp. 307-311.

FBGMR: Fujian Bureau of Geology and Mineral Resources, 1985. Regional Geology of Fujian Province, Geological Publishing House, Beijing 617pp., in Chinese, with detailed English abstract.

Guo, L.Z., Shi, Y.S. and Ma, R.S., 1983. On the formation and tectonic evolution of the Mesozoic-Cenozoic active continental margin and island arcs in the western Pacific area. Acta Geol. Sin. 1, pp. 11-20. 
Guo, L.Z., Shu, L.S., Shi, Y.S., Lu, H.F., Ma, R.S. and Zhang, Q.L., 1996. Research on the terrane tectonics in China. Chin. J. Geochem. 15 3, pp. 193-202.

Harris, N.B.W., Pearce, J.A. and Tindle, A.G., 1986. Geochemical characteristics of collisionzone magmatism. In: Coward, M.P. and Ries, A.C., Editors, 1986. Collision TectonicsGeol. Soc. Lond. Spec. Publ. 19, pp. 67-81.

Hibbard, M.J., 1979. Myrmekites as a marker between preaqueous and postaqueous phase saturation in granitic systems. Geol. Soc. Am. Bull. 90, pp. 1047-1062.

Hibbard, M.J., 1987. Deformation of incompletely crystallized magma systems: granitic gneisses and their tectonic implications. J. Geol. 95, pp. 543-561.

Hu, G.R. and Zhang, B.D., 1998. The Nd isotopic compositions and their source areas of the metamorphic basement of Central Jiangxi Province. Acta Petrol. Mineral. 17 1, pp. 35-39 in Chinese with English abstract.

Hutton, D.H., 1988. Granite emplacement mechanisms and tectonic controls: inferences from deformation studies. Trans. R. Soc. Edinb., Earth Sci. 79, pp. 245-255.

Jahn, B.M., Chen, P.Y. and Yen, T.P., 1976. Rb-Sr ages of granitic rocks in southeastern China and their tectonic significance. Geol. Soc. Am. Bull. 86, pp. 763-776.

Jahn, B.M., Zhou, X.H. and Li, J.L., 1990. Formation and tectonic evolution of southeastern China and Taiwan: isitopic and geochemical constraints. Tectonophysics 183, pp. 145-160.

JBGMR: Jiangxi Bureau of Geology and Mineral Resources, 1984. Regional Geology of Jiangxi Province, Geological Publishing House, Beijing 921pp., in Chinese, with detailed English abstract.

Liu, C.S., Zhu, J.C., Shen, W.Z. and Xu, S.J., 1990. Classification and meterial source of continental crust transformation series granitoids in South China. Acta Geol. Sin. 3 3, pp. $287-298$.

Lu, H.F., Yu, H.N., Ding, Y.W. and Zhang, Q.L., 1983. Changing stress field in the middle segment of the Tan-Lu fault zone, eastern China. Tectonophysics 98, pp. 253-270.

NIGMR: Nanjing Institute of Geology and Mineral Resources, 1987. Late Mesozoic volcanism of Zhejiang, Fujian, Jiangxi and GuandongGeological Memoir Series 1,12, Geological Publishing House, Beijing 290pp.

Pearce, J.A., Harris, N.B.W. and Tindle, A.G., 1984. Trace element discrimination diagrams for the tectonic interpretation of granitic rocks. J. Petrol. 25, pp. 956-983.

Ren, J.S. and Chen, T., 1989. Tectonic evolution of the continental lithosphere in eastern China and adjacent areas. J. Southeast Asian Earth Sci. 3, pp. 17-27.

Ren, J.S., Niu, B.G., He, Z.J., Xie, G.L. and Liu, Z.G., 1998. The geotectonic framework and its dynamic evolution of the eastern China. In: Liu, F.R., Editor, , 1998. The lithospheric 
texture and tectonic-magmatic evolution of the eastern China, Atomic Energy Publishing House, Beijing, pp. 1-11 in Chinese with English abstract.

$\mathrm{Ru}, \mathrm{K}$. and Pigott, T.D., 1986. Episodic rifting and subsidence in the South China sea. Am. Assoc. Petrol. Geol. 70 9, pp. 1136-1155.

Shu, L.S., Shi, Y.S., Guo, L.Z., Charvet, J. and Sun, Y., 1995. Plate tectonic evolution and the kinematics of collisional orogeny in the middle Jiangnan, eastern China, Nanjing University Publishing House, Nanjing 174pp., in Chinese with detailed English abstract.

Shu, L.S., Sun, Y., Wang, D.C., Faure, M., Monie, P. and Charvet, J., 1998. Mesozoic doming extensional tectonics of Wugongshan, South China. Sci. Chin. (Ser D) 41 6, pp. 601608 .

Sun, S.S. and McDonough, W.F., 1989. Chemical and isotopic systematics of oceanic basalts: implications for mantle composition and processes. In: Saunders, A.D. and Norry, M.J., Editors, 1989. Magmatism in the Ocean BasinsGeol. Soc. Lond. Spec. Publ. 42, pp. 313-345.

Tang, J.F., Wang, X.M., Liu, F. and Tang, C., 1991. Tectonic deformation and geological survey of the Wugongshan metamorphic terrane, China-University Geosciences, Publishing House, Wuhan 133 pp. (in Chinese).

Taylor, B. and Hayes, D.E., 1983. Origin and history of the South China Sea Basin. In: Hayes, D.E., Editor, , 1983. The Tectonic and Geologic Evolution of Southeast Asian Seas and Islands (Part 2)Am. Geophys. Union Monogr. 27, pp. 23-56. Abstract-GEOBASE

Taylor, S.R. and McLennan, S.M., 1985. The Continental Crust: Its Composition and Evolution, Blackwell Scientific Publications, Oxford 312 pp.

Wang, H.Z. and Mo, X.X., 1995. An outline of the tectonic evolution of China. Episodes 18 $1-2$, pp. 6-16.

Xie, D.K., Ma, R.S. and Zhang, Y.S., 1996. Continental crust growth and mantle plume in South China, Geological Publishing House, Beijing 91pp. (in Chinese with detailed English abstract).

Xu, K.Q., Sun, N., Wang, D.Z., Hu, S.X., Liu, Y.J. and Ji, S.Y., 1984. Petrogenesis of the granitoids and their metallogenetic relations in South China. In: Xu, K.Q. and Tu, G.Z., Editors, 1984. Geology of granites and their metallogenetic relations, Science Press, Beijing, pp. 1-31 (in Chinese).

Xu, S.J., Shen, W.Z., Wang, Y.X. and Yang, J.D., 1991. A study of Nd-Sr isotope of the Wugongshan granite. Chin. Sci. Bull. 13, pp. 1004-1006.

Yin, L., Pollard, P.J. and Hu, S.X., 1995. Geological and geochemical characteristics of the Yichun $\mathrm{Ta}-\mathrm{Nb}-\mathrm{Li}$ deposit, Jiangxi Province, South China. Econ. Geol. 90, pp. 577-585.

ZBGMR: Zhejiang Bureau of Geology and Mineral Resources, 1989. Regional geology of Zhejiang Province, Geological Publishing House, Beijing 617 pp. (in Chinese with detailed English abstract). 



\section{Figures}

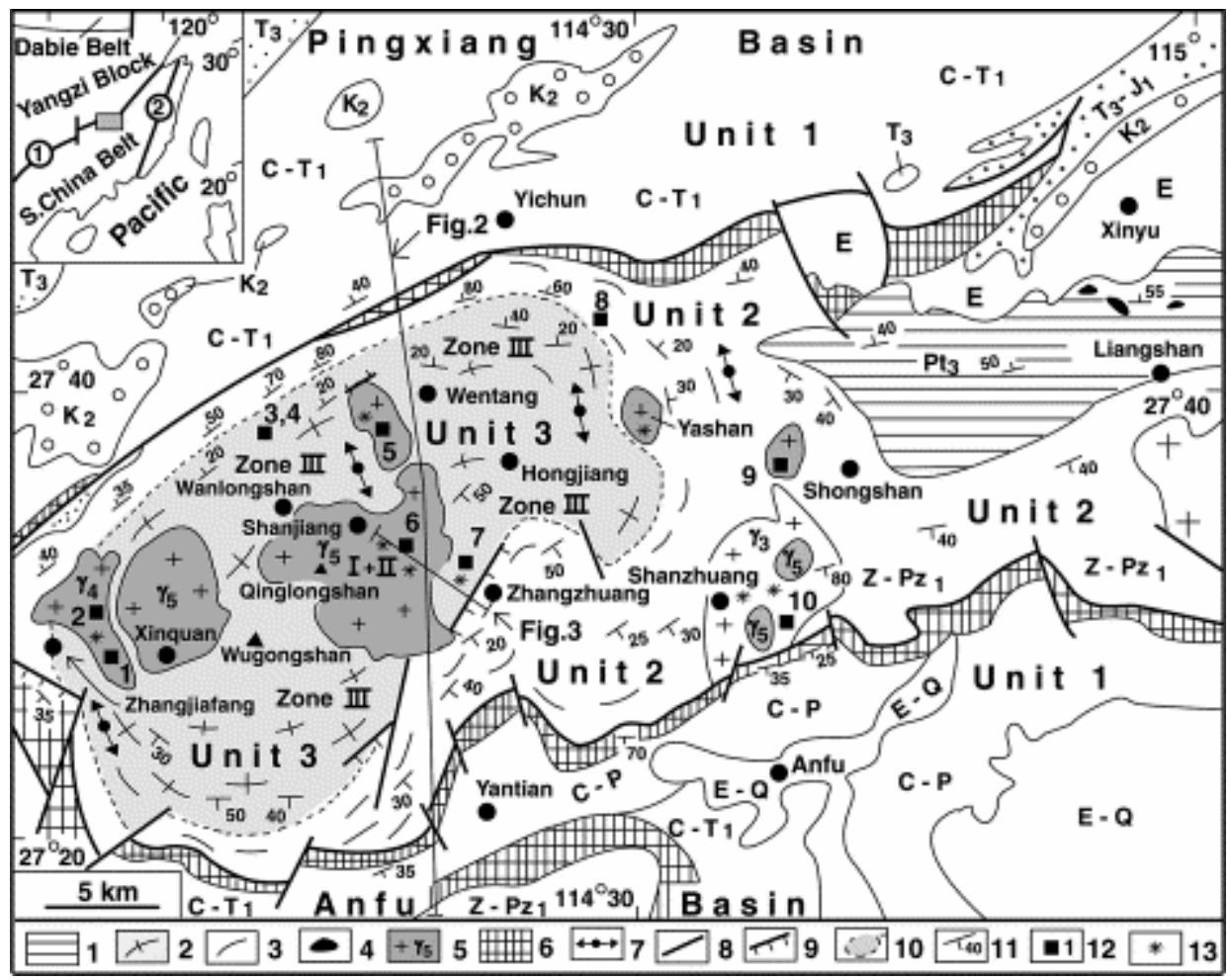

Fig. 1. Simplified geological map of Wugongshan dome with published age data and sampling localities for $\mathrm{Sm}-$ $\mathrm{Nd}, \mathrm{Rb}-\mathrm{Sr}$ isotopic studies. In the inset: (1) Pingxiang-Jiangshan-Shaoxing fault; (2) Zhenghe-Dapu fault. In this figure, legend: 1, Neo-Proterozoic schistose volcaniclastic rocks (phyllite and slate) with ultramafic blocks; 2, granitic gneissic rocks (Zone III of Unit 3 in the dome); 3, micaschist and phyllite within the Unit 2 of dome, and slate-phyllite out of the dome; 4, ultramafic block; 5, Yanshanian granitic rocks (Zone I and II in the inner rim of the dome) and oriented porphyroid K-granites (Zone II); 6, wearkly mylonitized Devonian quartzite and quartz sandstone; 7, coaxial shear along the lineation; 8 , large detachment ductile fault; 9 , ductile normal fault; 10, boundary between Unit 2 and Unit 3; 11, foliation; 12, radiometric dating point with sampling number; 13, $\mathrm{Sm}-\mathrm{Nd}$ and $\mathrm{Rb}-\mathrm{Sr}$ isotopic sampling point. In this figure, age data of Cubs 1, 3, 4, 6, 7 are from Faure et al. (1996); Cubs 2, 5, 8, 9 are from JBGMR (1984); Cub 10 is from Tang et al. (1991). 1, 259.0 $3.3 \mathrm{Ma}\left({ }^{40} \mathrm{Ar} /{ }^{39} \mathrm{Ar}\right.$ on biotite, granitic gneiss); 2, $237 \mathrm{Ma}\left(\mathrm{K}-\mathrm{Ar}\right.$ on biotite, granite); 3, 225.6 $2.9 \mathrm{Ma}\left({ }^{40} \mathrm{Ar} /{ }^{39} \mathrm{Ar}\right.$ on muscovite, granitic gneiss); 4, 229.0 $2.9 \mathrm{Ma}\left({ }^{40} \mathrm{Ar}{ }^{39} \mathrm{Ar}\right.$ on biotite, granitic gneiss); 5, $134 \mathrm{Ma}(\mathrm{K}-\mathrm{Ar}$ on biotite, granite); 6 , $131.7 \pm 1.7 \mathrm{Ma}\left({ }^{40} \mathrm{Ar} /{ }^{39} \mathrm{Ar}\right.$ on biotite, granite); 7, 233.5 $\pm 5.0 \mathrm{Ma}\left({ }^{40} \mathrm{Ar} /{ }^{39} \mathrm{Ar}\right.$ on muscovite, granitic gneiss $) ; 8$, $403 \mathrm{Ma}(\mathrm{K}-\mathrm{Ar}$ on muscovite, granitic gneiss); 9, $136 \mathrm{Ma}$ (K-Ar on biotite, granite); 10, $411 \mathrm{Ma}$ (Rb-Sr on whole rock, granitic gneiss).

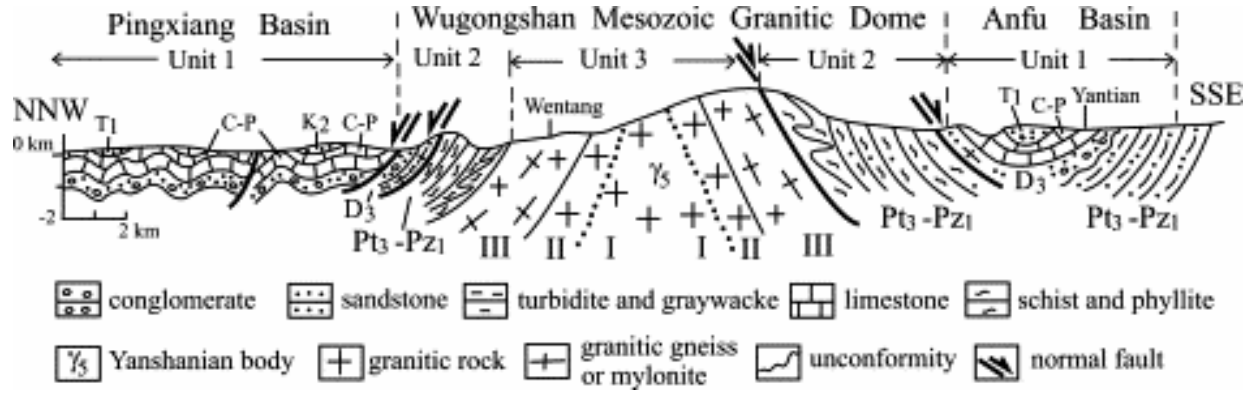

Fig. 2. Geological section through the Wugonghshan granitic dome and the Pingxiang and the Anfu basins. 


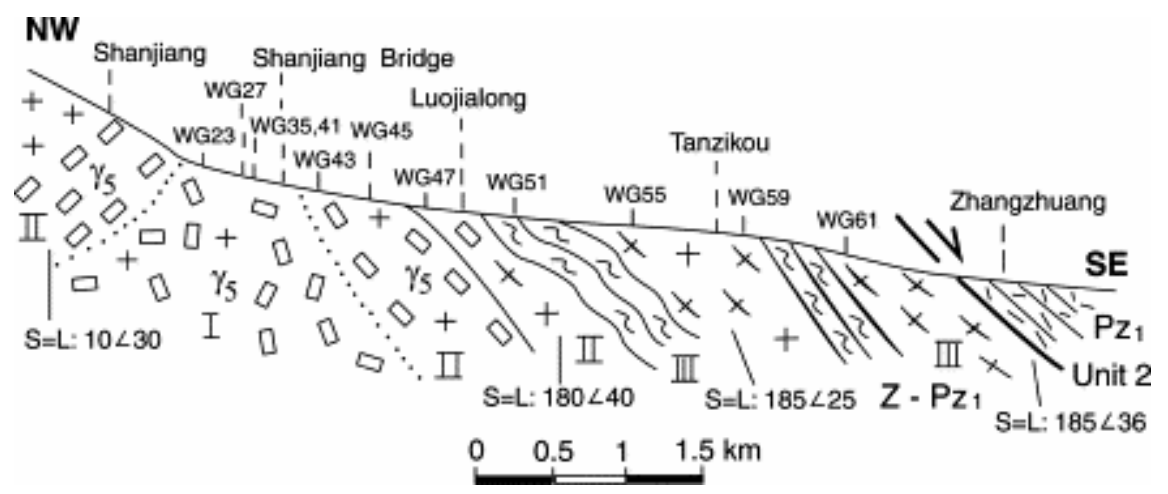

Fig. 3. Sub-NW-SE direction geological section for petrological and geochemical study from Zhangzhuang to Shanjiang, showing Petrographic zoning from center to outer rim in Unit 3 of the Wugongshan dome. Zones I, II and III are located in Unit 3 of the Wugongshan dome. Zone I, non-oriented porphyroidal leucogranite; Zone II, foliated granite with well oriented K-feldspar phenocrysts; Zone III, mylonitized granitic gneiss and biotiteplagioclase gneiss, containing typical minerals of sillimanite, garnet and neo-muscovite. Unit 2, micaschist and phyllite tuff. $\mathrm{r}_{5}$, Mesozoic granitoids; $\mathrm{Z}-\mathrm{Pz}_{1}$, metamophosed Sinian and Early Paleozoic rocks; $\mathrm{Pz}$, metamorphosed Early Paleozoic tuff and graywacke; S, foliation; L, stretching lineation.
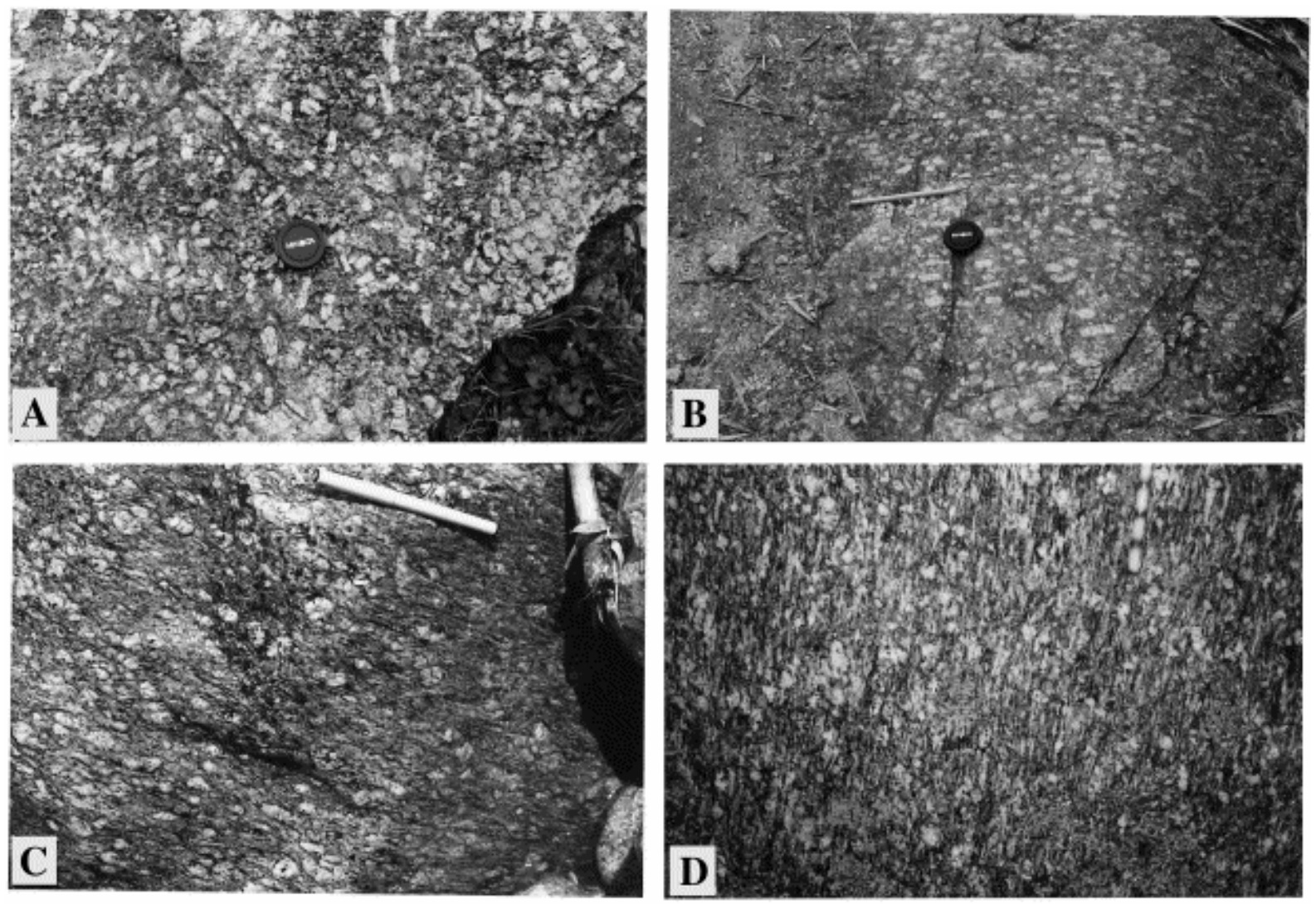

Fig. 4. Photographs of granitic rocks. A, giant grained non-oriented K-feldspar phenocryst (west $1500 \mathrm{~m}$ to Shanjiang Bridge); B, crystal mush structure of K-feldspar granite that is composed of well orientation of large and euhedral feldspar phenocrysts and medium grained groundmass (Shanjiang Bridge); $\mathrm{C}$, granitic gneiss with augen structure (Luojialong); D, granitic gneiss with sub-S-N direction stretching lineation (Tangzikou). 

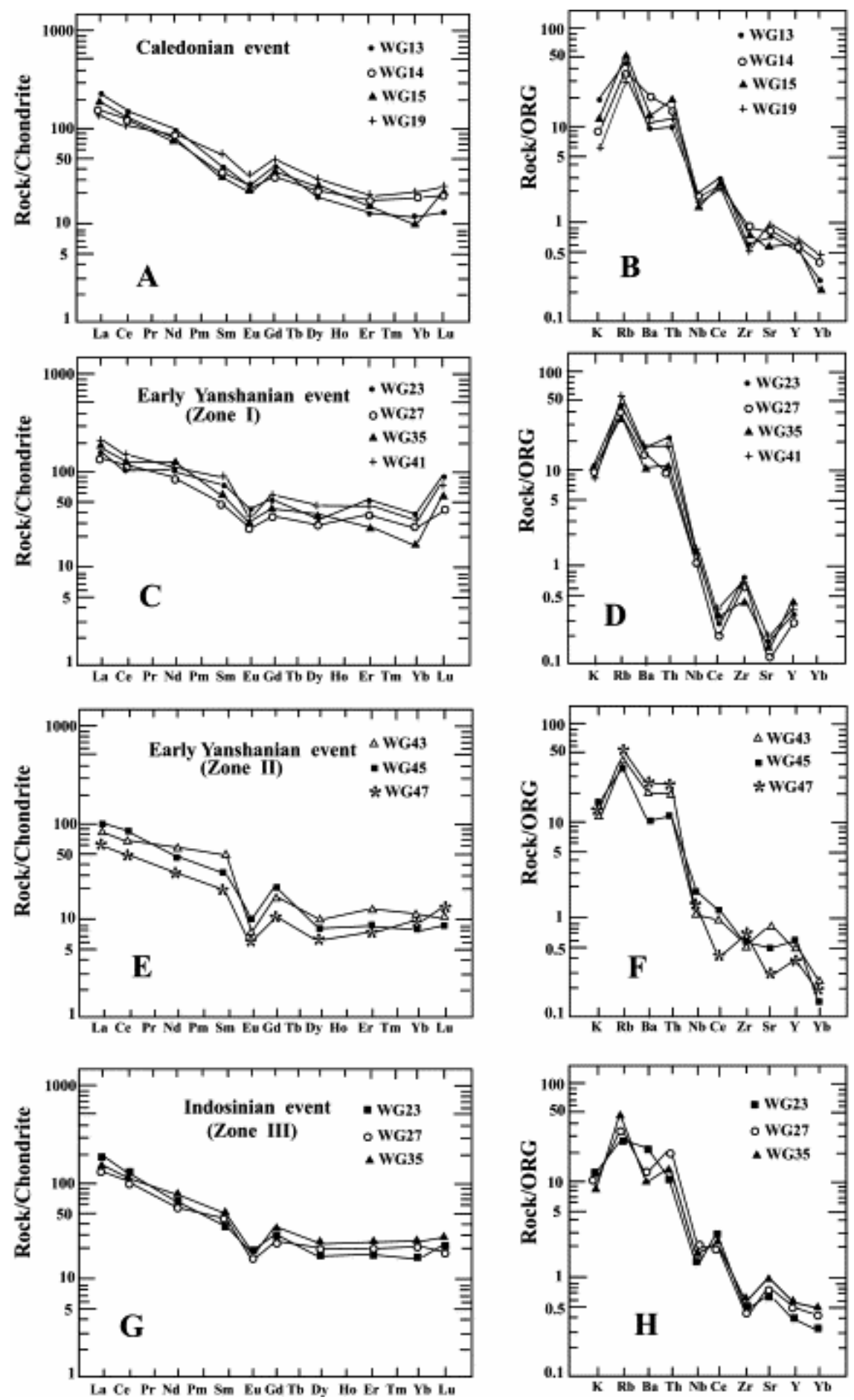

Fig. 5. REE patterns and spidergrams for granitoids of the Wugongshan granitic dome. A, B: REE patterns (A) and spidergrams (B) of the Caledonian granodiorote and dioritic enclaves; C, D: REE patterns (C) and spidergrams (D) of non-oriented porphyroidal leucogranites in Zone I; E, F: REE patterns (E) and spidergrams (F) of oriented porphyroidal leucogranites in Zone II; G, H: REE patterns $(\mathrm{G})$ and spidergrams $(\mathrm{H})$ of granitic gneisses in Zone III. 


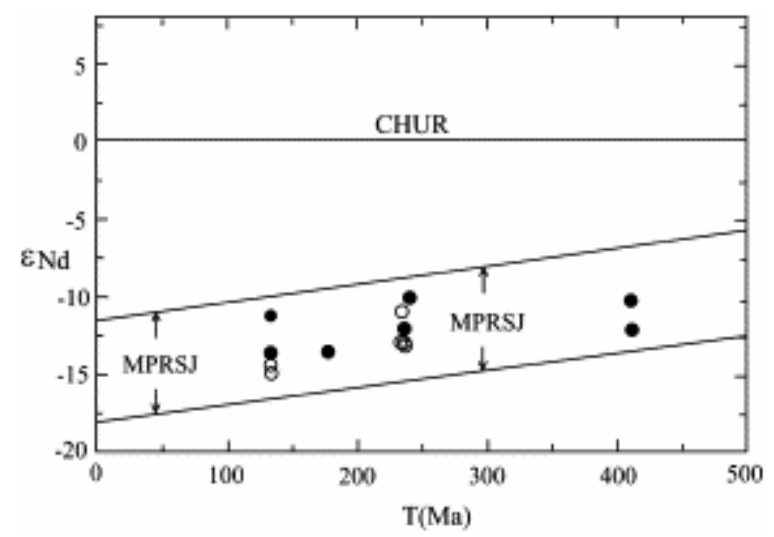

Fig. 6. The $T(\mathrm{Ma})-\quad$ Nd diagram suggesting a continental source for $\mathrm{Nd}$ composition of granitoids in the Wugongshan dome. CHUR, chondrite uniform reservoir; MPRSJ, Middle Proterozoic meta-sedimentary rocks in the southern Jiangxi Province, after Hu and Xie; black circle, analytical data of this paper; empty circle, after Liu and $\mathrm{Xu}$.

\section{Tables}


Table 1. Petrographic features of the Wugongshan granitoids, Jiangxi Province, Southeast China

\begin{tabular}{|c|c|c|c|c|c|c|c|}
\hline \multirow[b]{2}{*}{ Sample } & \multicolumn{4}{|c|}{ Shamzhuang Caledonian granodior ite } & \multicolumn{3}{|c|}{ Wugcngshan Mesozoic granitic pluton } \\
\hline & WG13 & WG14 & WG15 & WG19 & WG23 & WG 27 & WG35 \\
\hline Location & Qilingxia & Qilingxia & Shanzhuang & Shanzhuang & Shanjiang & Shanjiang & Shanjiang \\
\hline Texture & Gramular, gneissose & Granular, gieissose & Granular, gneissose & Intergranular & Porphyroidal & Porphyroidal & Porphyroidal \\
\hline Mineralogy & $\begin{array}{l}\text { Quartz }(25 \%) \text {, andesine } \\
\text { (An34) + digoclase } \\
\text { (An15) + K-feldspar } \\
\text { (50\%); biotite (20\%) } \\
\text { muscovite (<5\%), } \\
\text { amphibole (1-2\%), } \\
\text { accessory minerals } \\
(1 \%)\end{array}$ & $\begin{array}{l}\text { Quartz }(20 \%) \text {, andesine } \\
+\mathrm{K} \text {-feldspar + oligoclase } \\
(50-55 \%) \text {; biotite }(25 \%) \\
\text { amphibole }(2 \%) \text {, } \\
\text { muscovite }(<5 \%), \\
\text { accessory minerals } \\
(1 \%)\end{array}$ & $\begin{array}{l}\text { Quartz (20\%), } \\
\text { andesine (An30-40) } \\
\text { + K-feldspar (45\%), } \\
\text { oliogoclase (An20) } \\
\text { (10\%), bictite (15-20\%), } \\
\text { amphibole (2\%), } \\
\text { muscovite(5\%) }\end{array}$ & $\begin{array}{l}\text { Plagioclase (50\%), } \\
\text { homblende }(35 \%) \text {, } \\
\text { biotite }(5-10), \\
\text { quartz }(5 \%) \text {, } \\
\text { Fe-Ti oxides(3\%) }\end{array}$ & $\begin{array}{l}\text { Phenocryst: } \\
\text { potash feldspar (15\%), } \\
\text { muscovite + biotite( } 5 \%) \text {; } \\
\text { medium grained } \\
\text { groundmass: orthocline + } \\
\text { quartz + muscovite + } \\
\text { albite + biotite }(80 \%) \text {; } \\
\text { accessory minerals } 1 \%)\end{array}$ & $\begin{array}{l}\text { Phenocryst: } \\
\text { potash feldspar (15\%), } \\
\text { quartz + mica (10\%); } \\
\text { medium grained } \\
\text { groundmass: quartz + } \\
\text { microcline + albite } \\
\text { (An8) + muscovite (75\%) }\end{array}$ & $\begin{array}{l}\text { Phenocryst: } \\
\text { potash feldspar (20\%), } \\
\text { medium grained } \\
\text { groundmass }(80 \%) \text { ) } \\
\text { quartz + microcline + } \\
\text { bictite + albite (An5) + } \\
\text { muscovite }\end{array}$ \\
\hline \multirow[t]{3}{*}{ Name } & Granodiorite & Granodiorite & Granodiorite & Diorite (Enclave) & $\mathrm{K}$-feldspar granite & Leucogranite & $\mathrm{K}$-feldspar granite \\
\hline & \multicolumn{7}{|c|}{ Wugongshan Mesozoic ganitic pluton } \\
\hline & Zone I & Zone II & & & Zone III & & \\
\hline Sample & WG41 & WG43 & WG45 & WG47 & WGS1 & WGSS & WG59 \\
\hline Location & Shanjiang & Shanjiang Bridge & Shanjiang Bridge & Luojialong & Luojialong & Tamzikou & Tanzikou \\
\hline Texture & Porphyroidal & Porphyroidal & Porphyroidal & Porphyroidal & A ugen, gneissose & Augen, gneissose & Augen, gneissose \\
\hline Mineralogy & $\begin{array}{l}\text { Phenocryst: } \\
\text { K-feldspar (15\%); } \\
\text { medium grained } \\
\text { groundmass }(85 \%) \text { ) } \\
\text { quartz + microcline + } \\
\text { albite + muscovite + } \\
\text { biotite; } \\
\text { accessory minerals } \\
\text { (rare) }\end{array}$ & $\begin{array}{l}\text { Phenocryst (20\%): } \\
\text { potash feldspar }+ \\
\text { quartz + mica; } \\
\text { medium grained } \\
\text { groundmass }(80 \%) \text { : } \\
\text { quartz + microcline + } \\
\text { perthite + albite }+ \\
\text { muscovite + biotite; } \\
\text { acoessory minerals } \\
(1 \%)\end{array}$ & $\begin{array}{l}\text { Phenorryst(15-20\%): } \\
\text { microcline + quartz; } \\
\text { medium grained } \\
\text { groundmass ( } 80-85 \%) \text { : } \\
\text { quartz + microcline + } \\
\text { perthite + muscovite + } \\
\text { albite + biotite; } \\
\text { sillimanite (1-2\%); } \\
\text { accessory minerals } \\
\text { (rare) }\end{array}$ & $\begin{array}{l}\text { Phenocryst (15\%): } \\
\text { potash feldspar; } \\
\text { medium grained } \\
\text { groundmass }(85 \%) \text { : } \\
\text { quartz(25\%) + biotite } \\
(10 \%)+\text { albite }(10 \%)+ \\
\text { microcline }(20 \%)+ \\
\text { muscovite }(10-15 \%)+ \\
\text { gamet }(5 \%) ; \\
\text { sillimanite (1\%) }\end{array}$ & $\begin{array}{l}\text { Augen-microcline, } \\
\text { (15\%), quartz (5\%); } \\
\text { medium-fine gained } \\
\text { groundmass ( } 80 \%) \text { : } \\
\text { microcline (30), } \\
\text { quartz (25\%), } \\
\text { muscovite (15\%) } \\
\text { biotite }(5 \%) \text {, } \\
\text { albite ( } 5 \%) \text {, } \\
\text { sillimanite (1\%) }\end{array}$ & $\begin{array}{l}\text { Augen-quartz (5\%), } \\
\text { microcline (15\%); } \\
\text { groundmass (80\%): } \\
\text { microcline (20\%), } \\
\text { quartz (30\%), } \\
\text { muscovite (10-15\%), } \\
\text { abite (5\%), } \\
\text { biotite }(10 \%) \text {, } \\
\text { garnet }(3 \%)\end{array}$ & $\begin{array}{l}\text { Augen-microcline } \\
(10 \%) \text {; fine grained } \\
\text { groundmass (90\%): } \\
\text { muscovite(10\%) } \\
\text { quartz }(30 \%) \text {, } \\
\text { mirocline (30\%), } \\
\text { bictite }(10 \%) \text {, } \\
\text { albite (10\%), } \\
\text { acessory minerals } \\
(1 \%)\end{array}$ \\
\hline Name & Granite & Granite & Mica-granite & Muscovite granite & Greissose granite & Gneissose granite & Gneissose ganite \\
\hline
\end{tabular}



Table 2. EMPA mineral compositions of the Wugongshan granitoids, Jiangxi Province, Southeast China. Eu/Eu ${ }^{*}=(\mathrm{Eu} /((\mathrm{Sm}+\mathrm{Gd}) / 2) n ;$ normalized (n) to chondrites for rare earth elements after Sun and McDonough (1989) and to ORG for imcompatible elements after Pearce et al. (1984))

\begin{tabular}{|c|c|c|c|c|c|c|c|c|c|c|c|c|c|c|c|c|c|c|c|c|}
\hline \multirow{4}{*}{$\begin{array}{l}\text { Sample } \\
\text { Mineral } \\
\text { Number }\end{array}$} & \multirow{2}{*}{\multicolumn{7}{|c|}{$\begin{array}{l}\text { Shanzhuang Caledonian granodiorite } \\
\text { WG 13: granodiorite }\end{array}$}} & \multicolumn{13}{|c|}{ Wugonghhan Mesozoic granitic pluton } \\
\hline & & & & & & & & \multicolumn{5}{|c|}{ WG23: ganite (Zone I) } & \multicolumn{6}{|c|}{ WG27:leucogranite (Zone I) } & \multirow{2}{*}{\multicolumn{2}{|c|}{$\frac{\text { WG43: granite }}{\text { Microcline }}$}} \\
\hline & \multirow{2}{*}{$\begin{array}{l}\text { Oligoclase } \\
1\end{array}$} & \multicolumn{2}{|l|}{ Andesine } & \multicolumn{2}{|l|}{ Biotite } & \multicolumn{2}{|c|}{ Amphibole } & \multirow{2}{*}{$\frac{\text { Albite }}{8}$} & \multicolumn{2}{|c|}{ Microcline } & \multicolumn{2}{|l|}{ Bictite } & \multirow{2}{*}{$\frac{\text { Muscovite }}{13}$} & \multicolumn{2}{|c|}{ Microcline } & \multirow{2}{*}{$\frac{\text { Albite }}{16}$} & \multicolumn{2}{|l|}{ Gamet } & & \\
\hline & & 2 & 3 & 4 & 5 & 6 & 7 & & 9 & 10 & 11 & 12 & & 14 & 15 & & 17 & 18 & 19 & 20 \\
\hline $\mathrm{SiO}_{2}$ & 62.44 & 60.141 & 60.324 & 35.198 & 35595 & 43.401 & 44.195 & 66.86 & 64.972 & 64.562 & 35.115 & 35.183 & 46.032 & 66.535 & 66.753 & 68.166 & 37.334 & 37.751 & 64.694 & 65.668 \\
\hline $\mathrm{TiO}_{2}$ & 0.035 & 0.036 & 0.164 & 4521 & 4.485 & 1.213 & 1544 & 0.007 & 0 & 0.147 & 4.371 & 4592 & 0.138 & 0 & 0 & 0.019 & 0 & 0 & 0 & 0.096 \\
\hline $\mathrm{Al}_{2} \mathrm{O}_{3}$ & 22.162 & 23.292 & 22587 & 16.768 & 16.816 & 10.952 & 9536 & 23.313 & 19.445 & 19.825 & 19.779 & 19.962 & 35.65 & 17.374 & 17,44 & 20.097 & 22.901 & 22.843 & 17.764 & 17.076 \\
\hline $\mathrm{FeO}$ & 0.019 & 0.01 & 0 & 24.774 & 24.75 & 1753 & 1752 & 0.059 & 0.039 & 0.029 & 19.732 & 19.837 & 0.455 & 0 & 0.019 & 0.072 & 32.67 & 31.852 & 0 & 0.029 \\
\hline $\mathrm{MnO}$ & 0 & 0 & 0.01 & 0.506 & 0.378 & 0.56 & 0.529 & 0.003 & 0 & 0.04 & 0.288 & 0.266 & 0.292 & 0.033 & 0 & 0.025 & 2.696 & 2.92 & 0.022 & 0 \\
\hline $\mathrm{MgO}$ & 0.042 & 0.015 & 0 & 6.483 & 6.388 & 9.944 & 10.355 & 0 & 0 & 0.064 & 8.448 & 7505 & & 0.012 & 0 & 0.009 & 2.701 & 3.02 & & 0.004 \\
\hline $\mathrm{CaO}$ & 49 & 9.47 & 9595 & 0 & 0.021 & 12.111 & 12.085 & 1.133 & 0.534 & 0.046 & 0.008 & 0 & 0.054 & 0.002 & 0 & 1.998 & 1.532 & 1.412 & 0.019 & 0 \\
\hline $\mathrm{Na}_{2} \mathrm{O}$ & 9.971 & 6.897 & 7.192 & 0.219 & 0.171 & 1.277 & 1.132 & 7.14 & 0.456 & 0.589 & 0.352 & 0.146 & 1.175 & 0.795 & 0.673 & 9.035 & 0 & 0 & 0.761 & 0.866 \\
\hline $\mathrm{K}_{2} \mathrm{O}$ & 0.081 & 0.169 & 0.16 & 9.202 & 8932 & 1.063 & 1.019 & 2005 & 15.124 & 14.755 & 8.931 & 9.205 & 12.475 & 14.786 & 14.795 & 0.207 & 0.003 & 0.01 & 16.23 & 16.009 \\
\hline Total (wt:) & 99.65 & 100.03 & 100.032 & 97.671 & 97536 & 98.051 & 97.915 & 100.52 & 100.57 & 100.047 & 97.024 & 96.696 & 96.271 & 99.537 & 99.68 & 99.628 & 99.839 & 99.808 & 99.49 & 99.748 \\
\hline & $A n=15$ & & & & & & & & & & & & & & & & & & & \\
\hline
\end{tabular}

\begin{tabular}{|c|c|c|c|c|c|c|c|c|c|c|c|c|c|c|c|c|c|c|c|c|}
\hline \multirow{4}{*}{$\begin{array}{l}\text { Sample } \\
\text { Mineral } \\
\text { Number }\end{array}$} & \multicolumn{20}{|c|}{ Wugongshan Mescooic granitic plưon } \\
\hline & \multirow{2}{*}{\multicolumn{2}{|c|}{$\frac{\text { WG43: granite }}{\text { Biotite }}$}} & \multicolumn{8}{|c|}{ WG45: mica-granite (Zone II) } & \multicolumn{5}{|c|}{ WG47: muscovite granite (Zone II) } & \multicolumn{5}{|c|}{ WG51: gneisose granite (Zone III) } \\
\hline & & & \multirow{2}{*}{$\frac{\text { Muscovite }}{23}$} & \multicolumn{2}{|c|}{ Sillimanite } & \multirow{2}{*}{$\frac{\text { Biotite }}{26}$} & \multirow{2}{*}{$\frac{\text { Biotite }}{27}$} & \multicolumn{3}{|c|}{ Microcline } & \multicolumn{2}{|l|}{ Gamet } & \multirow{2}{*}{$\frac{\text { Sillimanite }}{33}$} & \multicolumn{2}{|c|}{ Microcline } & \multicolumn{2}{|l|}{ Garnet } & \multicolumn{2}{|c|}{ Microcline } & \multirow{2}{*}{$\frac{\text { Biotiv }}{40}$} \\
\hline & 21 & 22 & & 24 & 25 & & & 28 & 29 & 30 & 31 & 32 & & 34 & 35 & 36 & 37 & 38 & 39 & \\
\hline $\mathrm{SiO}_{2}$ & 34.854 & 34.346 & 44.962 & 33.906 & 33.921 & 34.606 & 33.829 & 65.014 & 64.45 & 66.276 & 37.407 & 38.061 & 33.973 & 65.257 & 65386 & 38.261 & 37.294 & 65.195 & 65.299 & 34.801 \\
\hline $\mathrm{TiO}_{2}$ & 4.198 & 2.591 & 0.121 & 0.037 & 0 & 4.094 & 3.923 & 0.023 & 0 & 0.08 & 0 & 0 & 0 & 0.091 & 0.062 & 0.072 & 0 & 0 & 0.006 & 4.072 \\
\hline $\mathrm{Al}_{2} \mathrm{O}_{3}$ & 19.655 & 19597 & 35.695 & 65.464 & 65.043 & 19.651 & 20.201 & 19.541 & 18.966 & 20.17 & 21.8 & 22.466 & 65.223 & 19.406 & 19.211 & 22862 & 22.701 & 20.06 & 19.961 & 18.975 \\
\hline $\mathrm{FeO}$ & 19.14 & 21.215 & 0.863 & 0.42 & 0.53 & 22.345 & 22.433 & 0 & 0.035 & 0.075 & 31.467 & 30.462 & 0.382 & 0 & 0.048 & 30.388 & 30.967 & 0.029 & & 24.037 \\
\hline MiO & 0.337 & 0.437 & 0.754 & 0.007 & 0.011 & 0.447 & 0.255 & 0 & 0 & 0.014 & 4.402 & 4.293 & 0.031 & 0.032 & 0.06 & 2506 & 3.382 & 0 & 0.027 & 0.383 \\
\hline $\mathrm{MgO}$ & 8.174 & & 1.002 & 0 & 0.035 & 6.014 & 5.799 & 0.052 & 0 & 0.017 & 3.12 & 3.146 & 0.104 & 0.027 & 0 & 4508 & 4.251 & 0.062 & 0 & 5569 \\
\hline $\mathrm{CaO}$ & 0 & 0.084 & 0.264 & 0.025 & 0.052 & 0.036 & 0 & 0.296 & 0 & 0 & 1577 & 1544 & 0.017 & 0.008 & 0.062 & 1529 & 1.57 & 0.101 & 0.004 & 0 \\
\hline $\mathrm{Na}_{2} \mathrm{O}$ & 0.193 & 0.122 & 0.368 & 0 & 0 & 0.067 & 0.384 & 0.596 & 0.605 & 0.213 & 0 & 0 & 0.121 & 0.703 & 0.559 & 0.093 & 0 & 1.202 & 1.226 & 0.026 \\
\hline & 8.986 & 8.663 & 11.2 & 0.001 & 0 & 7.704 & 8.632 & 15.053 & 14.972 & 14.99 & 0 & 0.002 & 0 & 14.901 & 14.834 & 0.004 & 0.011 & 13.379 & 13588 & 9.066 \\
\hline Total (wt\%) & 95.537 & 95.909 & 95.229 & 99.86 & 99.592 & 94964 & 95.456 & 100.575 & 99.028 & 101.435 & 99.73 & 99.974 & 99.851 & 100.425 & 100.16 & 100.223 & 100.183 & 100.028 & 100.11 & 96929 \\
\hline
\end{tabular}


Table 3. Major, incompatible and rare earth element compositions of the Wugongshan granitoids, Jiangxi Province, Southeast China. (Analytical errors for analyses carried out by ICP-OES are of $0.5 \mathrm{ppm}$ for concentrations $<10 \mathrm{ppm}$ and $5 \%$ for concentrations $>10 \mathrm{ppm}$. 2 . Gr: granite; )

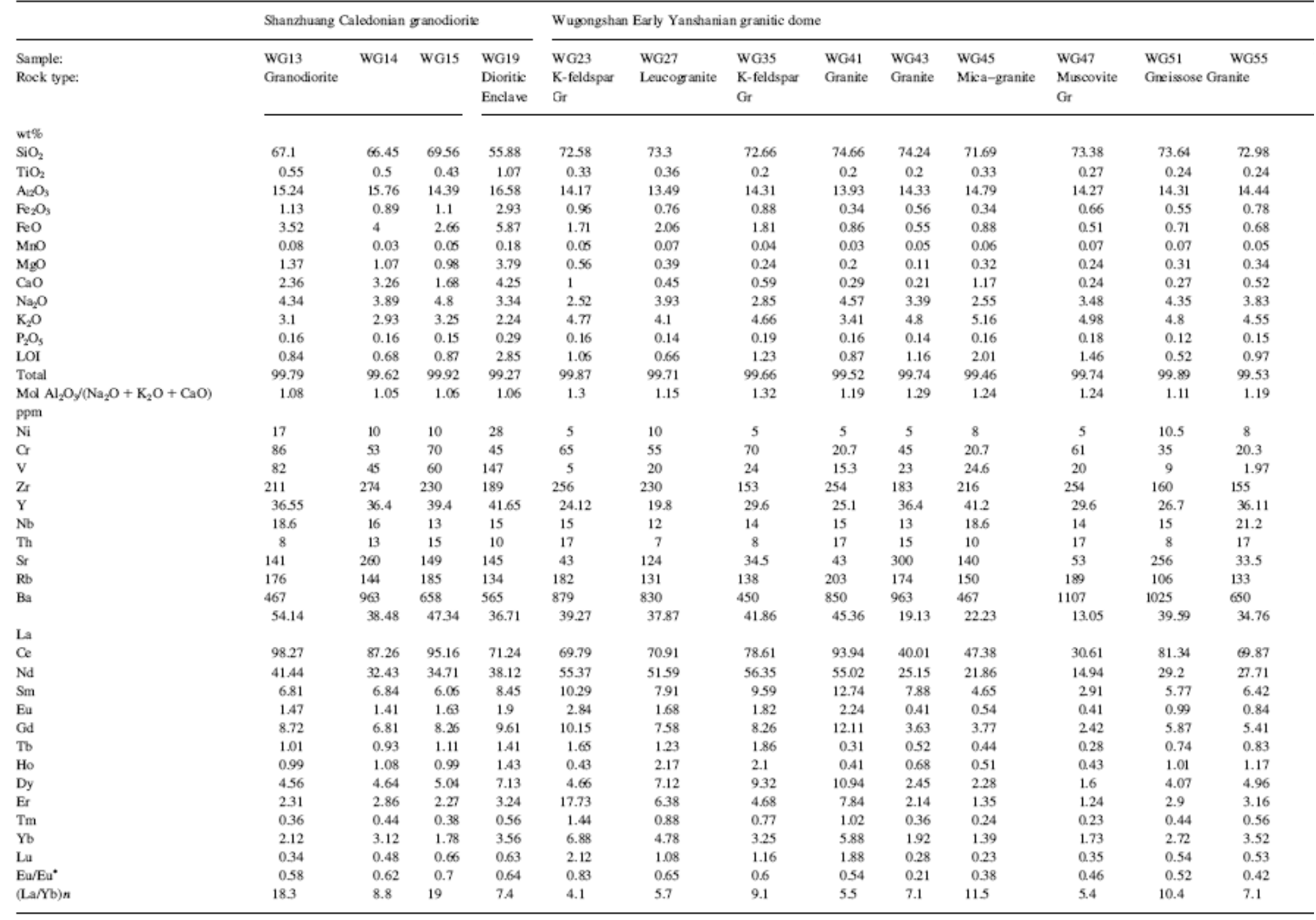


Table 4. $\mathrm{Rb}-\mathrm{Sr}$ and $\mathrm{Sm}-\mathrm{Nd}$ isotopic compositions of the Wugongshan granitoids, Jiangxi Province, Southeast China $\left(T_{\mathrm{DM}}=1 / \lambda \ln \left\{1+\left[\left({ }^{143} \mathrm{Nd} /{ }^{144} \mathrm{Nd}\right)_{\mathrm{m}}-\left({ }^{143} \mathrm{Nd} /{ }^{144} \mathrm{Nd}\right)_{\mathrm{DM}}\right]-\left[\left({ }^{147} \mathrm{Sm} /{ }^{144} \mathrm{Nd}\right)_{\mathrm{m}}-\left({ }^{147} \mathrm{Sm} /{ }^{144} \mathrm{Nd}\right)_{\mathrm{c}}\right]\left(\mathrm{e}^{\lambda t}-1\right) /\left[\left({ }^{147} \mathrm{Sm} /{ }^{144} \mathrm{Nd}\right)_{\mathrm{m}}-\left({ }^{147} \mathrm{Sm} /{ }^{144} \mathrm{Nd}\right)_{\mathrm{c}}\right]\right\} . \mathrm{In}\right.$ this formula, $m$ is the determined value of sample, $t$ is the crystallized age of sample, $\mathrm{c}$ is crust, DM is depleted mantle. $\lambda_{\mathrm{Sm}}=6.54 \times 10^{-12} \mathrm{a}^{-1}, \lambda_{\mathrm{Rb}}=1.42 \times 10^{-11} \mathrm{a}^{-1}$, $\left.\left({ }^{147} \mathrm{Sm} /{ }^{144} \mathrm{Nd}\right)_{\mathrm{c}}=0.118,\left({ }^{143} \mathrm{Nd} /{ }^{144} \mathrm{Nd}\right)_{\mathrm{DM}}=0.513151,\left({ }^{147} \mathrm{Sm} /{ }^{144} \mathrm{Nd}\right)_{\mathrm{DM}}=0.2136\right)$

\begin{tabular}{|c|c|c|c|c|c|c|c|c|c|c|c|c|c|}
\hline \multirow{4}{*}{$\begin{array}{l}\text { Location: } \\
\text { Rock type: } \\
\text { Sample: }\end{array}$} & \multirow{3}{*}{\multicolumn{2}{|c|}{$\begin{array}{l}\text { Shanzhuang Caledonian } \\
\text { granitoid }\end{array}$}} & \multicolumn{11}{|c|}{ Wugongshan Mesozoic granitoids } \\
\hline & & & \multicolumn{4}{|l|}{ Qinglongshan } & \multirow{3}{*}{$\begin{array}{l}\text { Yashan } \\
\text { Granite } \\
\text { WGI43 }\end{array}$} & \multirow{3}{*}{$\begin{array}{l}\frac{\text { Qinglongshan }}{\text { Gneissose granite }} \\
\text { WG59 }\end{array}$} & \multirow{2}{*}{\multicolumn{4}{|c|}{$\frac{\text { Wugongshan }}{\text { Gneissose granite }}$}} & \multirow{3}{*}{$\begin{array}{l}\text { Zhangiafang } \\
\text { Granite } \\
\text { WG-91 }\end{array}$} \\
\hline & & & \multicolumn{2}{|c|}{$\mathrm{K}$-feldspar granite } & \multicolumn{2}{|c|}{ Gneissose granite } & & & & & & & \\
\hline & WG13 & WG19 & WG23 & WG41 & $\mathrm{Zh}-7^{\mathrm{a}}$ & $\mathrm{Zh}-8^{\mathrm{a}}$ & & & WG- $15^{b}$ & WG-19 & WG- $83^{\circ}$ & WG- $85^{\circ}$ & \\
\hline Age (Ma): & 411 & 411 & $132 \pm 2$ & $132 \pm 2$ & 151 & 145 & $132 \pm 2$ & $234 \pm 5$ & $234 \pm 5$ & $234 \pm 5$ & $234 \pm 5$ & $234 \pm 5$ & 237 \\
\hline${ }^{87} \mathrm{Rb}$ & 696.4 & & 750.2 & & & & & 523.7 & & & & & 407.8 \\
\hline $\mathrm{Rb}\left(10^{-6}\right)$ & 213.7 & & 230.2 & & & & & 160.7 & 223.1 & 238.5 & 247.5 & 91.9 & 144.5 \\
\hline${ }^{86} \mathrm{Sr}$ & 60.38 & & 148.8 & & & & & 30.75 & & & & & 911.7 \\
\hline $\operatorname{Sr}\left(10^{-6}\right)$ & 53.99 & & 132.4 & & & & & 27.51 & 203.5 & 153.7 & 83.08 & 239.3 & 810.3 \\
\hline${ }^{87} \mathrm{Rb}^{186} \mathrm{Sr}$ & 11.53 & & 5.042 & & & & & 17.03 & 3.1793 & 4.5036 & 8.6546 & 1.0753 & 0.5164 \\
\hline${ }^{87} \mathrm{Sr}^{186} \mathrm{Sr}$ & 0.774099 & & 0.726418 & & & & & 0.778323 & 0.73016 & 0.74024 & 0.76074 & 0.72076 & 0.711547 \\
\hline $\pm 2 \sigma \mathrm{m}$ & 35 & & 14 & & & & & 39 & 2 & 3 & 3 & 4 & 12 \\
\hline$I_{\mathrm{gs}}$ & 0.706611 & & 0.716958 & & & & & 0.715575 & 0.719578 & 0.725251 & 0.728852 & 0.717181 & 0.70981 \\
\hline$\varepsilon_{\mathrm{St}}$ & 36.8 & & 179 & & & & & 161 & 218 & 299 & 350 & 184 & 80 \\
\hline${ }^{147} \mathrm{Sm}$ & 7.04 & 2.858 & 9.138 & 5.39 & 7.044 & 6.804 & 1.57 & 16.09 & & & & & 3.919 \\
\hline $\operatorname{Sm}\left(10^{-6}\right)$ & 7.059 & 2.865 & 9.163 & 5.404 & 7.06 & 6.811 & 1.574 & 16.13 & 3.508 & 5.266 & 5.529 & 3.517 & 3.93 \\
\hline${ }^{144} \mathrm{Nd}$ & 56.18 & 24.42 & 79.76 & 37.92 & 59.64 & 59.7 & 9.302 & 168.8 & & & & & 34.91 \\
\hline $\mathrm{Nd}\left(10^{-6}\right)$ & 34.07 & 14.81 & 48.37 & 23 & 35.95 & 36.15 & 5.641 & 102.4 & 16.848 & 25.27 & 26.787 & 16.023 & 21.17 \\
\hline${ }^{147} \mathrm{Sm}^{1 / 4} \mathrm{Nd}$ & 0.1253 & 0.117 & 0.1146 & 0.1421 & 0.11811 & 0.11397 & 0.1688 & 0.09533 & 0.12599 & 0.12606 & 0.12487 & 0.13281 & 0.1123 \\
\hline${ }^{143} \mathrm{Nd}^{n / 44} \mathrm{Nd}$ & 0.511831 & 0.511888 & 0.512 & 0.511889 & 0.511838 & 0.511803 & 0.51192 & 0.511815 & 0.511879 & 0.511878 & 0.511897 & 0.511981 & 0.511966 \\
\hline $\pm 2 \sigma \mathrm{m}$ & 7 & 8 & 5 & 8 & 12 & 20 & 8 & 7 & 13 & 20 & 13 & 16 & 9 \\
\hline$I_{\mathrm{Nd}}$ & 0.511494 & 0.511573 & 0.511901 & 0.511648 & 0.511736 & 0.511705 & 0.511723 & 0.511653 & 0.511686 & 0.511685 & 0.511685 & 0.511778 & 0.511794 \\
\hline$\varepsilon_{\mathrm{Nd}}$ & -12 & -10.5 & -11.1 & -13.7 & -14.3 & -14.9 & -13.4 & -12.7 & -12.7 & -12.7 & -12.1 & -10.9 & -10.5 \\
\hline$f(\mathrm{Sm} / \mathrm{Nd})$ & -0.36 & -0.41 & -0.42 & -0.28 & -0.4 & -0.42 & -0.14 & -0.52 & -0.36 & -0.36 & -0.37 & -0.32 & -0.43 \\
\hline$T_{\mathrm{DM}}(\mathrm{Ma})$ & 2128 & 2003 & 1825 & 2038 & 2103 & 2055 & 2050 & 2061 & 2040 & 2042 & 2011 & 1896 & 1870 \\
\hline
\end{tabular}

${ }^{a}$ From Liu et al. (1990).

${ }^{b}$ From Xu et al. (1991). 